\title{
Dysregulation of Astrocyte Ion Homeostasis and Its Relevance for Stroke-Induced Brain Damage
}

\author{
Michel J.A.M. van Putten ${ }^{1}{ }^{(D)}$, Christoph Fahlke ${ }^{2}$, Karl W. Kafitz ${ }^{3}$, Jeannette Hofmeijer ${ }^{1}$ and Christine R. Rose ${ }^{3, *(\mathbb{C})}$ \\ 1 Department of Clinical Neurophysiology, University of Twente, 7522 NB Enschede, The Netherlands; \\ m.j.a.m.vanputten@utwente.nl (M.J.A.M.v.P.); j.hofmeijer@utwente.nl (J.H.) \\ 2 Institut für Biologische Informationsprozesse, Molekular-und Zellphysiologie (IBI-1), \\ Forschungszentrum Jülich, 52425 Jülich, Germany; c.fahlke@fz-juelich.de \\ 3 Institute of Neurobiology, Heinrich Heine University Düsseldorf, 40225 Düsseldorf, Germany; \\ kafitz@hhu.de \\ * Correspondence: rose@hhu.de
}

Citation: van Putten, M.J.A.M.;

Fahlke, C.; Kafitz, K.W.; Hofmeijer, J.; Rose, C.R. Dysregulation of Astrocyte Ion Homeostasis and Its Relevance for Stroke-Induced Brain Damage. Int. J. Mol. Sci. 2021, 22, 5679. https:// doi.org/10.3390/ijms22115679

Academic Editors: Yukihiro Ohno and Schuichi Koizumi

Received: 19 April 2021

Accepted: 22 May 2021

Published: 26 May 2021

Publisher's Note: MDPI stays neutral with regard to jurisdictional claims in published maps and institutional affiliations.

Copyright: (C) 2021 by the authors Licensee MDPI, Basel, Switzerland. This article is an open access article distributed under the terms and conditions of the Creative Commons Attribution (CC BY) license (https:// creativecommons.org/licenses/by/ $4.0 /)$.
Abstract: Ischemic stroke is a leading cause of mortality and chronic disability. Either recovery or progression towards irreversible failure of neurons and astrocytes occurs within minutes to days, depending on remaining perfusion levels. Initial damage arises from energy depletion resulting in a failure to maintain homeostasis and ion gradients between extra- and intracellular spaces. Astrocytes play a key role in these processes and are thus central players in the dynamics towards recovery or progression of stroke-induced brain damage. Here, we present a synopsis of the pivotal functions of astrocytes at the tripartite synapse, which form the basis of physiological brain functioning. We summarize the evidence of astrocytic failure and its consequences under ischemic conditions. Special emphasis is put on the homeostasis and stroke-induced dysregulation of the major monovalent ions, namely $\mathrm{Na}^{+}, \mathrm{K}^{+}, \mathrm{H}^{+}$, and $\mathrm{Cl}^{-}$, and their involvement in maintenance of cellular volume and generation of cerebral edema.

Keywords: stroke core; penumbra; sodium; potassium; pH; chloride; glutamate transport; edema; cell swelling

\section{Introduction}

Cerebral ischemia is a pathological condition in which blood flow to the brain is insufficient to meet the brain's high metabolic demands. Ischemia may be focal, if a brain artery is occluded, leading to ischemic stroke or brain infarction. Cerebral ischemia may also affect the whole brain, for example during cardiac arrest. Reversible loss of cerebral functioning and irreversible damage come sequentially on time scales of minutes to days, depending on the remaining perfusion level and metabolic demand of the brain region at stake [1,2]. The only treatment of proven benefit is rapid reperfusion with $6-24 \mathrm{~h}$ after symptom onset. The sooner reperfusion is achieved, the better a patient's prognosis, reflecting the high vulnerability of the brain to hypoperfusion and hypoxia [3,4].

In ischemic stroke, perfusion levels may range from $<5 \mathrm{~mL} / 100 \mathrm{~g} / \mathrm{min}$ in the core of the affected vascular territory to $>35 \mathrm{~mL} / 100 \mathrm{~g} / \mathrm{min}$ in peripheral regions, through inflow of blood from surrounding arteries [5]. In the core, energy supply is classically insufficient to preserve ion gradients across the plasma membrane, with depolarization, $\mathrm{Ca}^{2+}$ influx, cell swelling, and irreversible cell damage within minutes [6]. In the surrounding regions, the so-called ischemic penumbra, synaptic activity may fail, but neurons and astrocytes initially remain structural intact and viable [7]. If blood flow is restored in time, cerebral dysfunction is, in principle, reversible (Figure 1). However, if oxygen and glucose are not resupplied, there will be progression towards irreversible failure of neurons and astrocytes on timescales of hours to days $[8,9]$. 

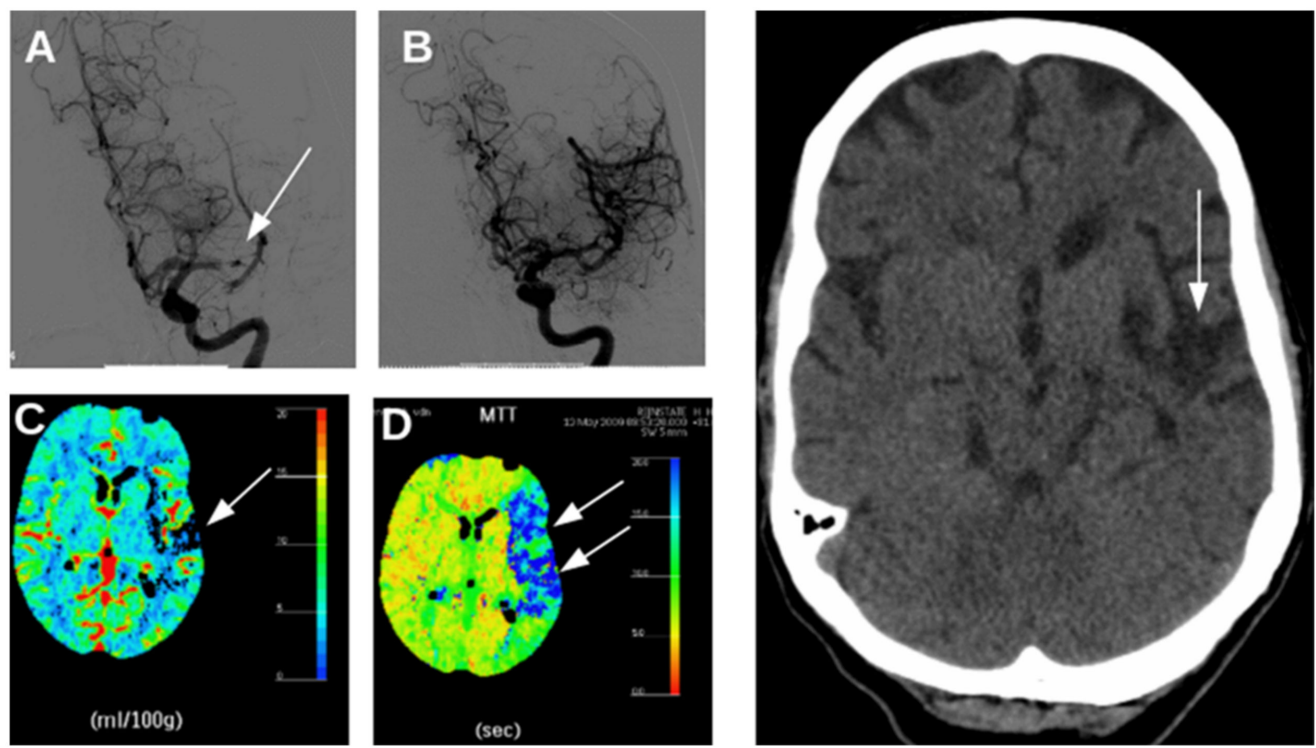

Figure 1. Radiology images from a patient with an acute ischemic stroke caused by occlusion of the left middle cerebral artery. (A): Digital subtraction angiography at $3 \mathrm{~h}$ after symptom onset obtained by intra-arterial administration of contrast agent, conforming middle cerebral artery occlusion. (B): revascularization after mechanical thrombectomy. (C): CT-perfusion maps, showing reduced cerebral blood volume (CBV) in a small part of the left hemisphere reflecting the infarct core (arrow) and (D) prolonged mean transit time (MTT) in a large part of the left hemisphere (blue tones in right panel, white arrows) reflecting hypoperfusion in the penumbra. Right: CT scan of the head 3 months after thrombectomy, showing a remaining lesion at the side of the previous infarct core (arrow), but recovery of brain areas that were part of the penumbra. The patient recovered completely.

Neurophysiological processes that contribute to recovery or ongoing damage are only partially understood. Increased concentrations of excitatory amino acids (mainly glutamate) in the extracellular space (ECS) will trigger excessive influx of cations through ionotropic glutamate receptors, namely NMDA, AMPA, and KA receptors, into the cell [10]. This is termed 'excitotoxicity', since the resulting prolonged depolarization and $\mathrm{Ca}^{2+}$ load will lead to activation of enzymes that degrade membranes, proteins, and nucleic acids [11,12]. 'Spreading depolarization' refers to propagation of neuronal and glial depolarization across the brain, resulting from diffusion of excitatory substances such as glutamate and $\mathrm{K}^{+}$through the ECS [13]. The strong cellular depolarization leads to suppression of all spontaneous or evoked electrical activity, a phenomenon referred to as 'spreading depression' [14,15].

Excitotoxicity and spreading depolarization are associated with transitions from reversible to irreversible neuronal damage in penumbral areas surrounding the infarct core. In peripheral regions of the penumbra, where remaining blood flow levels are presumably higher, persistent synaptic failure may result in lasting brain damage in the absence of membrane depolarization [16]. Of note, however, many studies discourage the overly simplified discrimination between infarct core and penumbra [17], and a vast heterogeneity with regard to cellular and molecular dynamics in core as well as penumbra has been demonstrated [18].

Many of the biochemical and electrophysiological processes contributing to neuronal damage during cerebral ischemia, such as glutamate release, depolarization, and synaptic modulations, are key to normal brain functioning and not harmful under physiological conditions. Damage comes from energy depletion impeding restoration of distorted homeostasis and ion gradients. Astrocytes play a key role in keeping brain homeostasis by ion buffering [19], synthesis and uptake of neurotransmitters [20], water transport [21], energy distribution [22], and immunomodulation [23,24]. For these reasons, astrocytes have been proposed as high potential candidate targets for neuroprotective treatments 
to prevent or delay transitions from reversible to irreversible neuronal damage in the penumbra [25-29]. In this context, many of the previous studies and reviews have focused on astrocytes' roles in immune responses, angiogenesis, $\mathrm{Ca}^{2+}$ buffering as potential targets to prevent cell death $[30,31]$ and/or emphasized the relevance of astrocyte activation upon stroke [32]. Here, we review the pivotal role of astrocytes at the tripartite synapse with a focus on energy supply and monovalent ion homeostasis, which form the basis of both physiological neuronal cell function and dysfunction under ischemic conditions.

\section{Energy Dependence of the Tripartite Synapse}

\subsection{Energy Needs of Neurons and Astrocytes}

The brain is a very hungry organ. In humans at rest, the CNS uses more than $20 \%$ of the entire $\mathrm{O}_{2}$ consumption and its energy needs relative to its weigh thus exceed those of all other organs $[33,34]$. Because ATP is mainly generated by mitochondrial respiration, the brain strictly depends on the continuous supply of oxygen and glucose, making it highly vulnerable to conditions of reduced blood flow.

Earlier estimates indicate that $25-40 \%$ of the cellular ATP are used for housekeeping processes not directly related to signalling such as turnover of microtubules, treadmilling of the actin cytoskeleton or lipid turnover [34,35]. The major share of ATP, however, is consumed by ion pumps embedded into plasma membranes and membranes of intracellular organelles responsible for the maintenance or re-establishment of ion gradients between different compartments [36-38]. Electrical signalling by neurons relies on the flux of ions and erodes these ion gradients. The subsequent restoration of ion gradients accounts for the majority of activity-related ATP consumption in the brain $[34,39,40]$. Astrocytes, which are in close spatial and functional relationships with neurons (Figure 2), are essentially electrically silent, and require only $5-10 \%$ of the total energy budget of neural activity $[39,40]$.
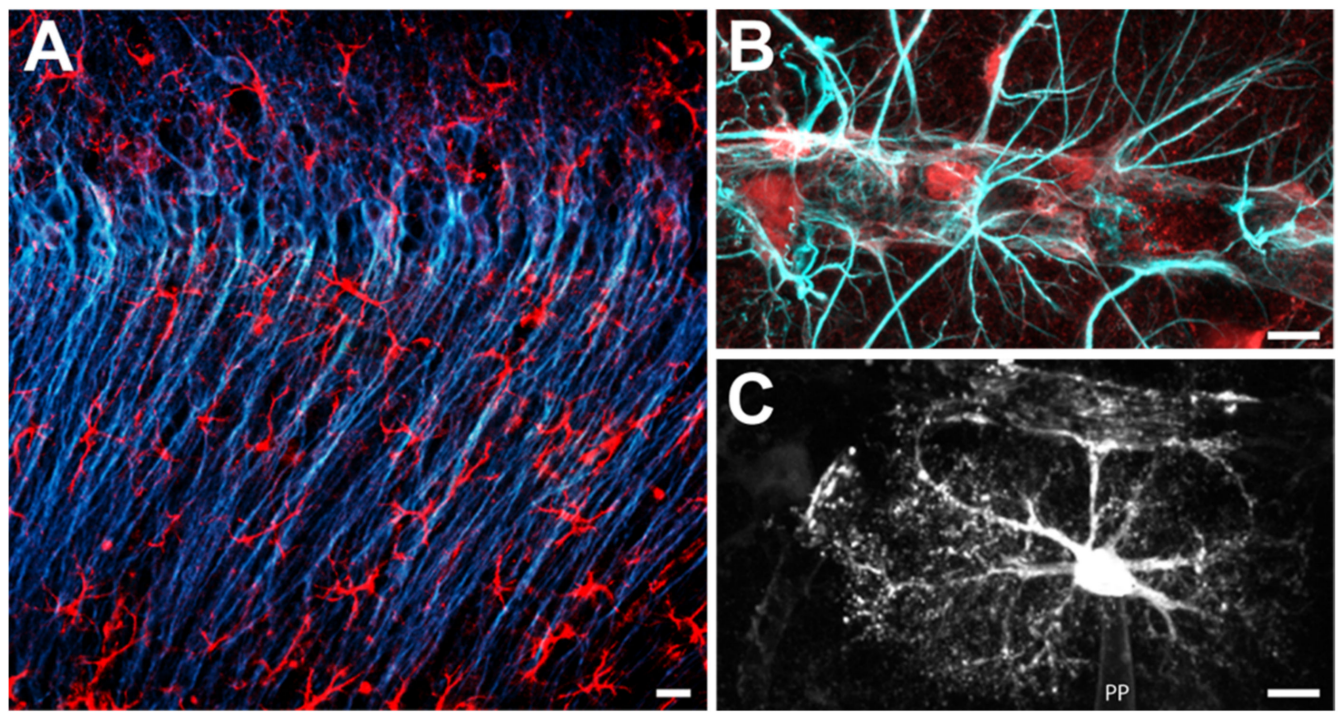

Figure 2. Astrocytes in the CA1 region of the mouse hippocampal formation. (A) Doubleimmunohistochemical labelling for the neuronal marker MAP-2 (blue) and for the astroglial marker GFAP (red). (B) Double-immunohistochemical labelling for the astroglial markers S-100 $\beta$ (red) and GFAP (light blue) along a blood vessel. Note the many processes that terminate at or parallel the blood vessel. (C) Astrocyte, dye-filled via a patch pipette (PP). Scale bars: (A) $5 \mu \mathrm{m}$; (B,C) $20 \mu \mathrm{m}$.

ATP is primarily used to enable the activity of ion pumps, most notably the $\mathrm{Na}^{+} / \mathrm{K}^{+}$ATPase (NKA) [41,42], the $\mathrm{Ca}^{2+}$-ATPases of the plasma membrane (PCMA) and endoplasmic reticulum (SERCA) [34,43] and the $\mathrm{H}^{+}$-ATPase of presynaptic vesicles (v-ATPase) [44-46] (see Figure 3). Among these pumps, the NKA is the major cellular energy consumer. 
The NKA establishes a low intracellular $\mathrm{Na}^{+}$concentration by exporting $3 \mathrm{Na}^{+}$against

$2 \mathrm{~K}^{+}[41,42,47,48]$, thereby generating the main driving forces for electrical signalling.

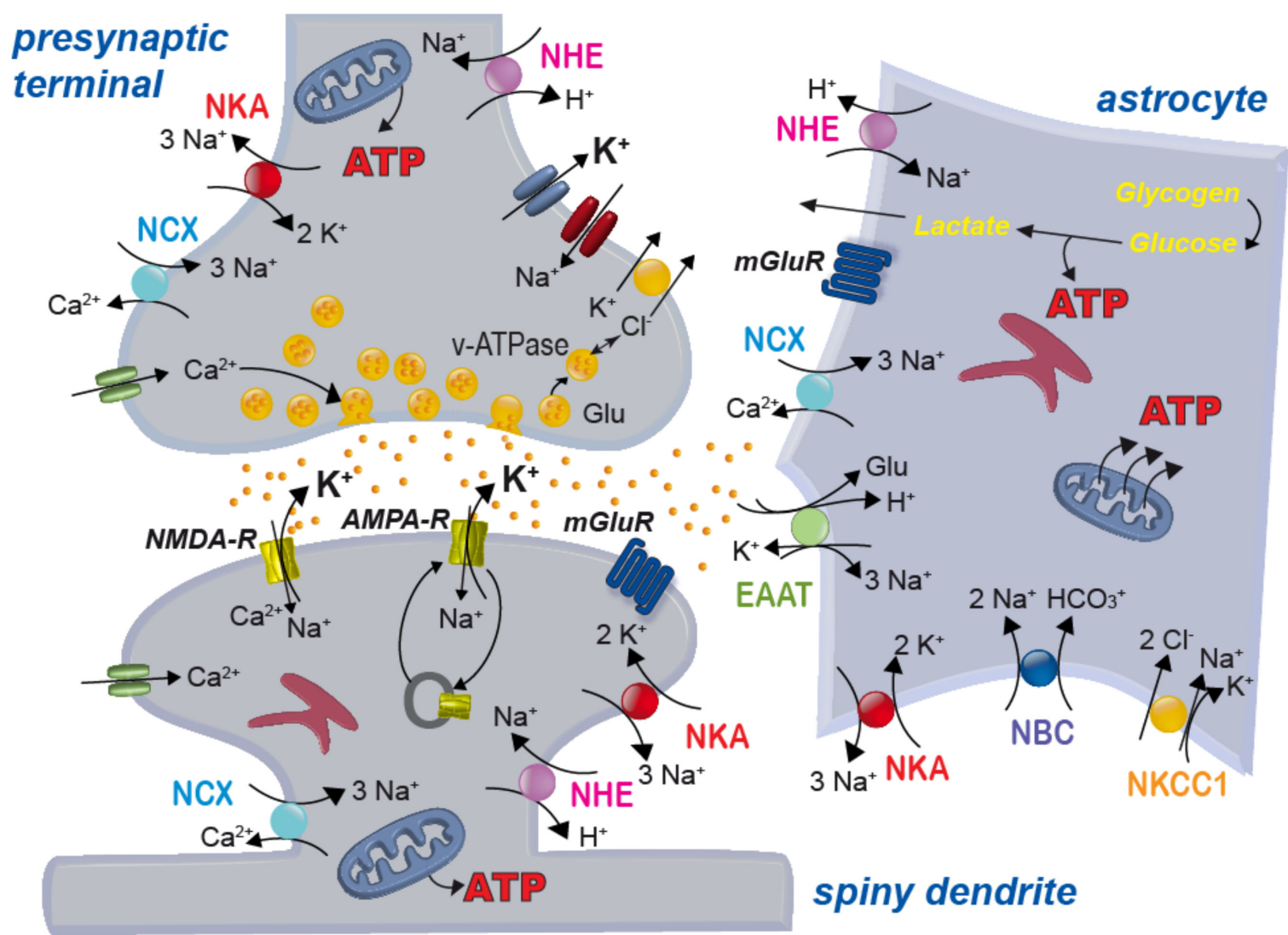

Figure 3. Scheme of a glutamatergic synapse and main ion transport mechanisms across the plasma membrane of neurons and astrocytes. NHE: sodium/proton exchanger; NKA: sodium/potassium-ATPase; NCX: sodium/calcium exchanger; NBC: sodium-bicarbonate-cotransporter; NKCC1: sodium-potassium-2 chloride cotransporter 1; EAAT: excitatory amino acid transporter; NMDA/AMPA-R: NMDA/AMPA-receptor; mGluR: metabotropic glutamate receptor; v-ATPase, vesicular ATPase; Glu: glutamate.

Besides its pivotal role for fast electrical signalling based on $\mathrm{Na}^{+}$and/or $\mathrm{K}^{+}$flux through ion channels, the NKA enables secondary-active transport, including the $\mathrm{Na}^{+} / \mathrm{Ca}^{2+}$ exchanger (NCX) or the $\mathrm{Na}^{+} / \mathrm{H}^{+}$exchanger (NHE) $[37,49]$ (see Figure 3). While these transporters do not consume ATP, a reduction in NKA activity from ATP depletion decreases $\mathrm{Na}^{+}$gradients, and indirectly affects their function. This not only may cause a reduction in transport rate. Depending on the severity of ATP shortage and the resulting breakdown of ion gradients, transporters may even reverse-with often detrimental consequences as is e.g., the case for $\mathrm{Na}^{+}$-dependent glutamate transport $[36,37,50,51]$, see also below.

\subsection{Neuro-Metabolic Coupling between Neurons and Astrocytes}

Chemical synapses of the vertebrate brain are usually illustrated as two-compartment systems consisting of a presynaptic terminal and a postsynaptic neuron. As a matter of fact, this is a rather simplified view. Neurons in the brain are surrounded by a narrow ECS that largely restricts diffusion. Recent super-resolution imaging studies in live tissue showed that the widths of the interstitial spaces, as determined in organotypic tissue slices of the CA1 area of the mouse hippocampus, ranges from $50 \mathrm{~nm}$ to over $1 \mu \mathrm{m}$ (median $270 \mathrm{~nm}$ ) and can change dynamically with neuronal activity [52]. Moreover, neurons do not have direct access to blood vessels. Still and despite these apparent restrictions, pre- and postsynaptic neuronal compartments-which are the major consumers of cellular 
ATP-need rapid and sufficient access to energy sources to cope with periods of high activity. Neurons, however, do not have any significant stores for metabolites that could quickly be fed into glycolysis or oxidative phosphorylation. Instead, astrocytes that contact synapses with their fine perisynaptic processes [53-55], are perfectly suited to help neurons out; exactly those cells that have an apparently low energy requirement on their own and store considerable amounts of glycogen [56,57]. In addition, perivascular endfeet of astrocytes essentially fully cover blood vessels, enabling direct uptake of glucose and $\mathrm{O}_{2}$ from the blood [58] (Figure 2).

There is overwhelming evidence for a key role of astrocytic glycogen in the healthy and diseased brain $[59,60]$. Moreover, direct neuro-metabolic coupling between neurons and astrocytes supports periods of high neuronal energy demand. Activity of neurons results in increased uptake of glucose from the blood by neighbouring astrocytes, accompanied by increased glycolysis and breakdown of glycogen [59,61]. Stimulation of astrocytic glycolysis by neuronal activity involves several mechanisms. A prominent role is played by the astrocytic sodium-bicarbonate-cotransporter (NBCe1) (Figure 3). NBCe1 is activated by $\mathrm{K}^{+}$released from active neurons, resulting in an intracellular alkalinization of astrocytes enhancing glycolysis [62]. Moreover, astrocytic glycolysis is stimulated by increases in intracellular $\mathrm{Na}^{+}$which accompany neuronal activity $[63,64]$. Lactate produced through glycolysis is then released from astrocytes and taken up by neurons $[61,65,66]$ (Figure 3). Analogous neuro-metabolic coupling was proposed for white matter, with oligodendrocytes supporting active neurons with lactate $[67,68]$. There is still substantial debate about the existence of the astrocyte-neuron-lactate shuttle in vivo ([62,69-73]), so further work is clearly needed to solve this issue. Activation of astrocytes' metabolism by neuronal activity, however, is undebated.

\subsection{Housekeeping by Astrocytes and the Tripartite Synapse}

As mentioned above, neurons in the brain are tightly packed and surrounded by a narrow ECS [52]. The properties of the ECS need to be tightly controlled which includes the regulation of the concentrations of ions and neurotransmitters. Astrocytes play centre stage in managing these tasks [74]. Their processes reach close to synapses, hindering diffusion in the narrow ECS [75]. In some brain areas, astrocytes even completely wrap around individual synapses, preventing spill-over of glutamate [76]. One of the first processes of neuron-glia interaction described was the ability of astrocytes to sense and control increases in extracellular $\mathrm{K}^{+}$concentration [77]. Even with prolonged neuronal activity (and accompanying release of $\mathrm{K}^{+}$), astrocytes keep extracellular $\mathrm{K}^{+}$concentrations below a ceiling level of 10-12 $\mathrm{mM}[78,79]$. This process, which is central to prevent uncontrolled depolarization of neurons [80], is mainly mediated by uptake of $\mathrm{K}^{+}$by the astrocyte NKA [81,82]. As a consequence, elevation of extracellular $\mathrm{K}^{+}$results in a decrease in the intracellular $\mathrm{Na}^{+}$concentration of astrocytes [83-85]. In addition, uptake of $\mathrm{K}^{+}$by astrocytes involves Kir4.1 channels [86]. The sodium-potassium-2 chloride-cotransporter 1 (NKCC1) (Figure 3) mediates astrocytic $\mathrm{K}^{+}$uptake under conditions of strongly elevated extracellular $\mathrm{K}^{+}$[81]. Once taken up, $\mathrm{K}^{+}$can pass through gap junctions and this process, called spatial buffering, helps to redistribute $\mathrm{K}^{+}$in the astrocyte network [86].

Astrocytes also control the extracellular concentration of the major neurotransmitters. Among the most essential tasks is the uptake of glutamate by high-affinity excitatory amino acid transporters (EAAT) (Figure 3), namely the glutamate aspartate transporter 1 (GLAST /EAAT1) and glutamate transporter 1 (GLT1/EAAT2). Glutamate uptake by astrocytes is absolutely critical for brain function since it protects neurons from glutamatemediated overexcitation (termed excitotoxicity) [20,87-89]. Once taken up, glutamate can be converted to $\alpha$-ketoglutarate and be fed into the TCA cycle $[90,91]$. Alternatively, it is converted to glutamine, which is exported into the ECS and again taken up by neurons to serve as a precursor for synthesis of glutamate or GABA [87].

In addition to fulfilling homeostatic roles, astrocytes actively contribute to signaling at synapses. Such active interaction can be triggered by astrocytic $\mathrm{Ca}^{2+}$ transients and 
involves their release of neuroactive substances, such as ATP and glutamate, which bind to receptors on surrounding neurons. At glutamatergic synapses, astrocyte $\mathrm{Ca}^{2+}$-signaling is e.g., induced upon activation of metabotropic glutamate receptors (mGluR5), at least in the juvenile brain [92,93]. Other pathways for the generation of astrocyte $\mathrm{Ca}^{2+}$ transients include reverse NCX, TRPA1 channels or P2Y1 receptors [94]. In consideration of this active role, the term "tripartite" synapse was introduced [95-97]. It acknowledges the fact that communication, information transfer and plasticity of chemical synapses involve more than the two neuronal cells, but include a third, astrocytic, compartment. As for the astrocyte-neuron-lactate shuttle, this topic is still partly questioned in the field [98,99]. There are many excellent reviews to which the reader is referred here $[54,55,94,100,101]$.

\section{Relevance of Astrocytic Cation Homeostasis}

\subsection{Sodium Homeostasis}

Astrocytes maintain a low intracellular $\mathrm{Na}^{+}$concentration of $10-15 \mathrm{mM}$ at rest, which is achieved by the action of the NKA, the only relevant export pathway for $\mathrm{Na}^{+}$across the plasma membrane $[49,102]$. Astrocytes predominately express $\alpha 2 / \beta 2$ subunits of the NKA, which exhibit a $\mathrm{K}_{\mathrm{D}}$ of $\sim 4 \mathrm{mM}$ for extracellular $\mathrm{K}^{+}$, making it ideally suited to take up $\mathrm{K}^{+}$ released by active neurons [103]. NKA thus not only determines intracellular $\mathrm{Na}^{+}$and $\mathrm{K}^{+}$ of astrocytes, but also contributes to regulation of extracellular $\mathrm{K}^{+}$.

Astrocyte $\mathrm{Na}^{+}$homeostasis is deeply intermingled with the regulation of all other major ions through secondary and tertiary $\mathrm{Na}^{+}$-dependent transporters. It is thereby directly coupled to homeostasis of intracellular $\mathrm{Ca}^{2+}$ (through NCX) and intracellular $\mathrm{pH}$ (through NHE and NBCe1) [49,51,102]. Notably, NCX is readily reversible, and increases in astrocytic $\mathrm{Na}^{+}$may turn $\mathrm{Ca}^{2+}$ export into import, resulting in intracellular $\mathrm{Ca}^{2+}$ signaling [51]. Another transporter that works close to its reversal potential is the NBCe1 [104,105]. Besides regulating ion homeostasis, the $\mathrm{Na}^{+}$gradient enables the uptake of transmitters from the ECS trough the aforementioned $\mathrm{Na}^{+}$-dependent glutamate transporters EAAT1 and EAAT2 as well as through transporters for GABA $[106,107]$.

While keeping astrocytic $\mathrm{Na}^{+}$low is critical for the function of an entire battery of $\mathrm{Na}^{+}$-dependent transporters, it has become clear that activation of the latter in response to neuronal activity also results in well-detectable transient increases in intracellular $\mathrm{Na}^{+}[74,102,108,109]$. Activity-induced $\mathrm{Na}^{+}$transients are largest in fine astrocytic processes close to activated synapses, but-depending on strength and pattern of activity-may also occur in somata or perivascular endfeet [110]. Major $\mathrm{Na}^{+}$-loaders for astrocytes are the EAATs, which can increase astrocytic $\mathrm{Na}^{+}$by up to $10 \mathrm{mM}$ with short burst stimulation of glutamatergic fibers [111-113]. In addition, $\mathrm{Na}^{+}$-permeable ion channels, among them AMPA or NMDA receptors expressed by some types of astrocytes may contribute to $\mathrm{Na}^{+}$ signals $[74,111,114]$. Subsequent export of $\mathrm{Na}^{+}$is primarily mediated by the NKA, but a $\left(\mathrm{Na}^{+}\right.$-driven) reversal of the NCX may assist the NKA in exporting $\mathrm{Na}^{+}[51,109]$. Upon induction of local influx, $\mathrm{Na}^{+}$rapidly diffuses to non-stimulated areas, thereby readily passing gap junctions and invading neighboring cells [110,115-117]. Because lateral diffusion will reduce local activation of the NKA, this re-distribution of $\mathrm{Na}^{+}$is likely to result in a distribution of the metabolic load within the astrocytic syncytium.

\subsection{Sodium Dysregulation and Its Consequences under Ischemic Conditions}

Intracellular $\mathrm{Na}^{+}$homeostasis is directly coupled to the NKA and inhibition of NKA results in an immediate rise in $\mathrm{Na}^{+}$in cultured astrocytes even under resting conditions [84,118]. Because NKA requires ATP to function, intracellular $\mathrm{Na}^{+}$homeostasis is also strictly dependent on an intact energy metabolism $[36,119]$. An increase in intracellular $\mathrm{Na}^{+}$and a resulting breakdown of the $\mathrm{Na}^{+}$gradient are thus immediate and primary consequences of energy deprivation arising from failure of cellular ATP production $[36,37,109,120]$.

$\mathrm{Na}^{+}$loading in response to metabolic inhibition can be easily demonstrated in resting cultured astrocytes. Chemical ischemia induced by blockers of glycolysis and oxidative 
respiration results in an instant rise in $\mathrm{Na}^{+}$in cultured spinal cord and cortical/forebrain astrocytes as well as in C6 glioma cells [118,121-123]. The degree of $\mathrm{Na}^{+}$dysbalance is dependent on the specific preparation as well as on the severity and duration of energy deprivation. This is also true for the intact tissue. In acute slices of the mouse neocortex, perfusion with metabolic inhibitors for 2 min transiently increased $\mathrm{Na}^{+}$by $\sim 8 \mathrm{mM}$ and a 5 -min perfusion by $30 \mathrm{mM}$ [124]. This protocol mimicked transient $\mathrm{Na}^{+}$accumulations by $10-20 \mathrm{mM}$ that were observed in the ischemic penumbra of the mouse neocortex in vivo during peri-infarct depolarisations (PIDs) [124]. While in vivo data are not available from ischemic core regions, astrocytic $\mathrm{Na}^{+}$loading is certainly substantially higher in the core $[37,50]$.

The consequences of an increase in intracellular $\mathrm{Na}^{+}$under ischemic conditions are manifold. Elevating astrocyte $\mathrm{Na}^{+}$activates glycolysis and breakdown of glycogen, and astrocytes might be able to produce lactate for a limited period of time by anaerobic glycolysis [62,125-127]. It is unclear if an uptake of astrocyte-derived lactate by neurons would be solely beneficial under hypoxic conditions, because it is accompanied by uptake of protons, exacerbating cellular acidosis and thereby possibly exacerbating neuronal damage [128].

The increase in intracellular $\mathrm{Na}^{+}$during energy deprivation is also accompanied by a reduction of the astrocytic membrane potential [129]. In astrocytes of acute hippocampal slices, an initial slow rise, followed by a faster and more prominent depolarization to a plateau was observed in response to oxygen-glucose deprivation for $30 \mathrm{~min}$ [130]. In addition to influx of $\mathrm{Na}^{+}$, an increase in extracellular $\mathrm{K}^{+}$was identified as a major cause for the astrocyte depolarization $[130,131]$. Its degree again depends on the preparation, model system and on the severity/duration of ATP depletion. Notably, both membrane depolarization and $\mathrm{Na}^{+}$loading not only affect astrocytes themselves, but will severely impact neuron-glia interaction, and thereby, synaptic transmission. Considering the above-described roles of astrocytes in ionic homeostasis and re-uptake of transmitters in which $\mathrm{Na}^{+}$homeostasis is involved, the resulting functional effects are significant, if not even dramatic.

Disturbance of astrocytic metabolism by sodium fluoroacetate (NaFAc), which selectively inhibits the enzyme aconitase in astrocytes [132], not only elevated intracellular $\mathrm{Na}^{+}$, but also caused a significant reduction in their $\mathrm{K}^{+}$uptake via the NKA [83]. As a result, extracellular $\mathrm{K}^{+}$transients accompanying burst firing of neurons were increased in amplitude and duration. In addition, the astrocyte's capacity to take up glutamate was reduced [83]. This was accompanied by a prolongation of neuronal burst firing, indicating increased neuronal excitability [83].

While in the above-mentioned studies, $\mathrm{Na}^{+}$increases were moderate $(10-20 \mathrm{mM})$, and thus in the same range as those observed during PIDs in vivo [124], the situation will differ in the ischemic core. Here, strong cellular depolarization together with a presumed substantial increase in intracellular $\mathrm{Na}^{+}$will likely cause reverse operation of glutamate transporters [133]. Such reversal will drive accumulation of glutamate in the ECS, causing drive excitotoxicity and cell death $[50,125,133-136]$. Importantly, cell death in response to extracellular glutamate accumulation not only relates to neurons, but has also been described for neocortical astrocytes and oligodendrocytes [137].

In addition to transport reversal, ischemic conditions may result in $\mathrm{Ca}^{2+}$-dependent vesicular release of glutamate from astrocytes $[97,138,139]$. In mice subjected to a transient $\mathrm{MCAO}$, spreading depolarisations travelling across the cortical penumbra are accompanied by transient $\mathrm{Ca}^{2+}$-increases in astrocytes, mediated both by influx through TRPV4 channels and by reverse NCX $[124,140]$. $\mathrm{Na}^{+}$-driven reversal of NCX could thus augment such vesicular release of glutamate from astrocytes [51,108,141]. Moreover, reverse NCX-mediated $\mathrm{Ca}^{2+}$-loading might directly harm astrocytes inducing mitochondrial $\mathrm{Ca}^{2+}$ overload and $\mathrm{Ca}^{2+}$-dependent cell death [141-143]. 


\subsection{Potassium}

Studies providing direct experimental data on intracellular $\mathrm{K}^{+}$concentrations in astrocytes are rare. The main reason is the lack of reliable indicators for $\mathrm{K}^{+}$imaging, necessitating the use of (invasive) ion-selective microelectrodes (e.g., [144,145]). Mostly based on such invasive studies, it has been established that astrocytic $\mathrm{K}^{+}$concentration is about 10 -fold higher than that of $\mathrm{Na}^{+}$[146]. This was confirmed by a more recent imaging approach employing the chemical indicator APG-1, in which a $\mathrm{K}^{+}$concentration of about $130 \mathrm{mM}$ was determined for cultured astrocytes at rest [147]. Astrocyte $\mathrm{K}^{+}$is mainly governed by the NKA [146]. Another transporter coupling transport of both ions is NKCC1, albeit mediating influx of $\mathrm{K}^{+}$into astrocytes [148]. Finally, $\mathrm{Na}^{+}$-dependent glutamate transporters (EAATs) export $1 \mathrm{~K}^{+}$per transport cycle [20]. Astrocytes also show substantial expression of different types of voltage-dependent plasma membrane $\mathrm{K}^{+}$ channels, KIR4.1 being the most prominent one [146,149].

Under physiological conditions, astrocytes take up $\mathrm{K}^{+}$released from active neurons by both channel- and transport-mediated mechanisms and thereby regulate neuronal excitability $[37,82,103,146]$. Exogenous application of glutamate, in contrast, resulted in a decline in astrocytic $\mathrm{K}^{+}$, most likely as a consequence of activation of EAATs [147]. Movement of $\mathrm{K}^{+}$ across the plasma membrane mediated by the above-mentioned mechanisms is opposed to that of $\mathrm{Na}^{+}$(e.g. [83]), again exemplifying the close interrelation between both ions.

There is a wealth of data and investigations demonstrating that energy restriction and accompanying spreading depolarization events are accompanied by a failure of extracellular $\mathrm{K}^{+}$-homeostasis in which astrocytes are critically involved [134,150-152]. A recent study also proposed an involvement of microglia in extracellular $\mathrm{K}^{+}$-homeostasis during spreading depolarisations [153]. In most models of prolonged energy failure, extracellular $\mathrm{K}^{+}$initially rises slowly up to a ceiling level of about $10-12 \mathrm{mM}$, upon which there is a second steep rise to a plateau of more than 50-60 mM [125,129,134]. Failure of astrocyte NKA is a major reason for the breakdown of the $\mathrm{K}^{+}$ceiling level, ultimately also leading to a loss of $\mathrm{K}^{+}$from astrocytes [131]. Loss of astrocytic $\mathrm{K}^{+}$will be further promoted by ATP-sensitive $\mathrm{K}^{+}$-channels ( $\mathrm{K}_{\mathrm{ATP}}$ ), which open upon a decline in intracellular ATP [24]. Knockout of Kir6.1, the pore-forming unit of astrocytic $\mathrm{K}_{\mathrm{ATP}}$, aggravated ischemic lesions und edema in the mouse brain [154].

$\mathrm{K}^{+}$efflux from astrocytes under ischemic conditions aggravates the accumulation of extracellular $\mathrm{K}^{+}$induced by its release from neurons. The substantial elevation of extracellular $\mathrm{K}^{+}$in turn activates NKCC1, driving import of $\mathrm{Na}^{+}, \mathrm{K}^{+}$and $\mathrm{Cl}^{-}$and resulting in substantial cellular swelling of astrocytes $[155,156]$. Inhibition of NKCC1 significantly reduces infarct volumes, making this transporter highly relevant in the generation of ischemic damage in the brain $[143,157]$ (see also below).

\section{4. $p H$}

Astrocytes maintain an intracellular $\mathrm{pH}$ in the range of 7.2 (corresponding to a proton concentration of $63 \mathrm{nM}$ ) at rest $[158,159]$. Like $\mathrm{Ca}^{2+}$, protons are heavily buffered in the cytosol, the $\mathrm{HCO}_{3}{ }^{-} / \mathrm{CO}_{2}$ system being the major mechanism of buffering [158]. Astrocyte $\mathrm{pH}$ is higher than expected from a passive distribution of protons, so export of acid equivalents into the ECS is required to counteract intracellular acidification [160]. Two $\mathrm{Na}^{+}-$ dependent transporters are involved in the regulation of intracellular $\mathrm{pH}$ [159]. One is the NHE, more specifically the isoform NHE1, which mediates the electroneutral exchange of protons with $\mathrm{Na}^{+}$[143]. The second transporter is $\mathrm{NBCe} 1$, which transports $\mathrm{HCO}_{3}{ }^{-}$along with $2 \mathrm{Na}^{+}$across the membrane. NBCe1 operates close to its reversal potential and can thereby serve as an acid extruder, acidifying the ECS, an as well as an acid loader, removing acid equivalents from the ECS $[158,160]$. The latter dampens extracellular acidifications accompanying neuronal activity [161].

Inhibition of metabolism and ischemic conditions cause a rapid drop in extracellular $\mathrm{pH}$, which-depending on the depth and duration of ischemia-may reach values between 6.5 and $6.9[120,162-164]$. Waves of spreading depolarization result in transient, but 
long-lasting acidification of the ischemic cortex of rats [165]. Acidosis accompanying ischemia is a harmful event, reducing astrocyte glutamate uptake [166] and exacerbating cytotoxic edema and cellular damage [167]. When exposed to a low extracellular $\mathrm{pH}$, astrocytes are unable to maintain their $\mathrm{pH}$ above 7 , but acidify and may even undergo cell death $[159,162,168]$. Moreover, inhibition of anaerobic metabolism moreover results in an intracellular acidification of astrocytes as a consequence of glycogen breakdown and glycolytic production of lactate [169]. The subsequent strong activation of NHE1 ameliorates intracellular acidosis-while at the same time serving as a strong pathway for $\mathrm{Na}^{+}$loading, promoting cellular swelling and cell death $[123,143,170,171]$.

In contrast to NHE1, NBCe1 has been reported to serve a predominately neuroprotective role [172]. In astrocytes derived from human-induced pluripotent stem cells, pharmacological inhibition of NBCe1 resulted in increased cell death in response to exposure to ischemic conditions [163]. Again, while inwardly-directed NBCe1 will dampen the astrocytic acidification, $\mathrm{Na}^{+}$influx will be aggravated-with all the negative consequences outlined above. NBCe1 has also been implemented in astrocyte swelling [173], which, if this process is operative under ischemic conditions, will most likely promote tissue damage.

Notably, a recent study reported a direct causal relationship between glial $\mathrm{pH}$ and glutamate-related excitoxicity in the cerebellum [174]. Induction of proton influx into Bergmann glial cells through activation of channelrhodopsin-2 resulted in a decrease in intracellular $\mathrm{pH}$, triggering a release of glutamate from the glial cells. Conversely, optogenetic induction of proton export from Bergmann glial cells reduced their release of glutamate and significantly reduced ischemic brain damage in vivo [174]. These results suggested that $\mathrm{pH}$-dependent glial glutamate release contributes to excitotoxic cell death. Glial acidosis thus emerged as one of the mechanisms inducing neuronal damage in the ischemic brain [175].

\section{Relevance of Astrocytic Chloride Homeostasis}

\subsection{Regulation of Intracellular Chloride Levels}

Chloride $\left(\mathrm{Cl}^{-}\right)$is the most abundant anion in the human body, and every cell of our body expresses multiple $\mathrm{Cl}^{-}$channels and transporters to adjust $\mathrm{Cl}^{-}$concentrations in the cytoplasm and in cell organelles. Water flux out of the cell or into the cell is always linked to $\mathrm{Cl}^{-}$fluxes in the same direction, making the intracellular $\mathrm{Cl}^{-}$concentration $\left(\left[\mathrm{Cl}^{-}\right]_{\mathrm{i}}\right)$ a main determinant of cell swelling and regulatory volume changes [176,177]. Volume regulation and thus $\mathrm{Cl}^{-}$homeostasis are especially important for astrocytes, since they undergo fast changes in cell volume when exposed to osmotic gradients [178-181]. Moreover, changes in osmotically active solute concentrations are intimately associated with glial key functions.

Despite its high physiological importance, $\left[\mathrm{Cl}^{-}\right]_{\mathrm{i}}$ has only been determined for few cell types, and mechanisms underlying intracellular $\mathrm{Cl}^{-}$homeostasis remain insufficiently understood $[182,183]$. So far, glial $\left[\mathrm{Cl}^{-}\right]_{\mathrm{i}}$ has been experimentally addressed in cultured astrocytes with results varying between of 29-46 $\mathrm{mM}$ [184-189]. In acute mouse brain tissue slices, fluorescence lifetime imaging microscopy (FLIM) with the $\mathrm{Cl}^{-}$-sensitive dye MQAE [190-192] provided a $\left[\mathrm{Cl}^{-}\right]_{\mathrm{i}}$ of $34 \mathrm{mM}$ for cerebellar Bergmann glia cells [192,193]. These high values predict a $\mathrm{Cl}^{-}$reversal potential positive to the resting potential in glial cells. Astrocytes express $\mathrm{GABA}_{\mathrm{A}}$ receptors $\left(\mathrm{GABA}_{\mathrm{A}} \mathrm{Rs}\right)[194,195]$, anion-selective channels that open upon binding of GABA to an extracellular binding site. In cultured astrocytes and as well as in astrocytes in acute brain slices, electrophysiological experiments demonstrated astrocyte depolarization upon activation of $\mathrm{GABA}_{\mathrm{A}}$ receptors $[196,197]$, in agreement with astrocytic $\left[\mathrm{Cl}^{-}\right]_{i}$ significantly higher than expected for a passive distribution.

A combination of specific inhibitors and genetically altered animals was used to identify anion transporters responsible for setting $\left[\mathrm{Cl}^{-}\right]_{\mathrm{i}}$ in Bergmann glial cells [193]. Blocking NKCC1 decreased $\left[\mathrm{Cl}^{-}\right]_{i}$. Genetic ablation as well as pharmacological inhibition of EAATs and block of potassium-chloride cotransporters (KCC) resulted in its rise. $\left[\mathrm{Cl}^{-}\right]_{\mathrm{i}}$ of Bergmann glia is thus in dynamic equilibrium between transport processes that accumulate $\mathrm{Cl}^{-}$, such as NKCC1, and transporters or channels that move $\mathrm{Cl}^{-}$out of the cells, such as 
KCC1 and KCC3 or EAAT anion channels [193]. It is safe to assume that astrocytes exhibit similar mechanisms of intracellular $\mathrm{Cl}^{-}$homeostasis.

The importance of cation $\mathrm{Cl}^{-}$cotransporters for cellular $\mathrm{Cl}^{-}$homeostasis has been known for many years [198-201]. However, the involvement of glutamate transporters came as surprise. EAATs are not only secondary-active glutamate transporters, but also anion channels [202-204], with anion channel opening being closely linked to conformational changes underlying glutamate transport [205-207]. A role in regulating $\left[\mathrm{Cl}^{-}\right]_{\mathrm{i}}$ in glia was one of the first cellular functions unambiguously assigned to EAAT anion channels. $\left[\mathrm{Cl}^{-}\right]_{\mathrm{i}}$ was studied at different developmental stages, revealing a glial $\mathrm{Cl}^{-}$switch [193], which is reminiscent of the neuronal $\mathrm{Cl}^{-}$switch [182]. In very young animals (P5-6), the Bergmann glial intracellular $\mathrm{Cl}^{-}$concentration was $>50 \mathrm{mM}$, and dropped to the adult value of $34 \mathrm{mM}$ around $\mathrm{P} 14$. This $\mathrm{Cl}^{-}$switch coincides with the age-related upregulation of EAAT1/GLAST and EAAT2/GLT-1 [208], and block of both glial glutamate transporters increases $\left[\mathrm{Cl}^{-}\right]_{\mathrm{i}}$ in adult Bergmann glia to juvenile levels. Changes in glial $\mathrm{Cl}^{-}$homeostasis caused by mutations in SLC1A3 that encodes EAAT1 play a central role in the disease pathogenesis of certain forms of episodic ataxia, an inherited neurological conditions. A severe form of episodic ataxia characterized by ataxia and epilepsy was associated with a proline by arginine substitution at position 290 in EAAT1 [209]. This mutation increased the activity of EAAT1 anion channels, and enhanced mutant EAAT1-mediated $\mathrm{Cl}^{-}$efflux between P8 and P13 triggers Bergmann glia shrinking and apoptosis in an animal model of this disease [210,211].

All (astro-)glial $\left[\mathrm{Cl}^{-}\right]$determined thus far are clearly above the expectations for passive distributions, and at present, NKCC1 is the only candidate to actively accumulate $\mathrm{Cl}^{-}$ (Figure 4). We therefore should expect significantly decreased astrocytic $\left[\mathrm{Cl}^{-}\right]_{\mathrm{i}}$ in knock-out animals or in patients carrying mutation in SLC12A2 (the gene encoding NKCC1) that might impair various brain functions. This was, however, not the case. In Slc12a2-/-mice, synaptic density and brain morphology were not profoundly altered [212,213]. There are naturally occurring mutations that abolish NKCC1 expression [214] or impair transport functions [215]. In one of them, reduced cerebral volume and enlarged arachnoid spaces were shown at the age of 9 months [214]. It thus appears from these studies that glial active $\mathrm{Cl}^{-}$accumulation is not absolutely crucial for many brain functions. Alternatively, there might exist additional yet to be identified $\mathrm{Cl}^{-}$accumulating transport processes.

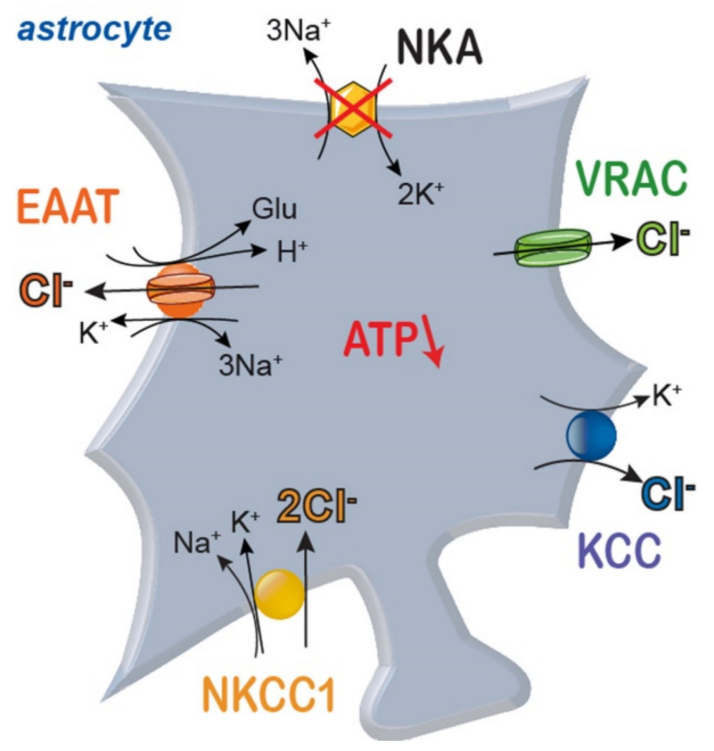

Figure 4. Scheme of main pathways for transport of $\mathrm{Cl}^{-}$across astrocyte membranes. NKA: sodium/potassium-ATPase; NKCC1: sodium-potassium-2 chloride cotransporter 1; EAAT: excitatory amino acid transporter; KCC: potassium-chloride cotransporter; VRAC: volume-activated anion channels. 


\subsection{Chloride and Ischemia}

All astrocytic anion transport processes are controlled by parameters that are expected to change during brain ischemia. As discussed above, energy restriction will reduce the activity of the NKA and consequently $\mathrm{Na}^{+}$and $\mathrm{K}^{+}$gradients across glial membranes. The resulting membrane depolarization increases ambient glutamate concentration under ischemic stress. The consequences on glial $\left[\mathrm{Cl}^{-}\right]_{\mathrm{i}}$ however, can at present not be decisively predicted. There is convincing data that demonstrates NKCC1-mediated $\mathrm{Cl}^{-}$accumulation in astrocytes under ischemic conditions [143,216-220]. The expected ischemia-associated drop in astrocytic $\left[\mathrm{K}^{+}\right]$would, however, also stimulate $\mathrm{Cl}^{-}$outward transport by KCCs. EAAT anion channels will be stimulated by increased extracellular glutamate, but the astrocytic depolarization might invert $\mathrm{Cl}^{-}$efflux into $\mathrm{Cl}^{-}$influx. Finally, since $\left[\mathrm{Cl}^{-}\right]_{\mathrm{i}}$ is in dynamic equilibrium between $\mathrm{Cl}^{-}$accumulation and outward transport/efflux, the consequences of ischemia on glial $\mathrm{Cl}^{-}$homeostasis will also depend on the starting values of $\left[\mathrm{Cl}^{-}\right]_{\mathrm{i}}$ in a given cell and preparation.

In astrocytes, stimulation of NKCC1 by increased extracellular $\mathrm{K}^{+}$not only results in accumulation of $\mathrm{Cl}^{-}$, but also in glial swelling during ischemia $[143,216-220]$ and in opening of volume-activated anion channels (VRACs or VSOCs, [221-223]). These channels permit $\mathrm{Cl}^{-}$efflux and allow regulatory volume decreases together with $\mathrm{K}^{+}$efflux through channels active under resting conditions. Volume-activated anion channels exhibit large pore diameters, and channel activation results in glutamate efflux and excitotoxic tissue damage [224]. Steric and electrostatic interactions with $\mathrm{Cl}^{-}$might result in changes of neurotransmitter efflux upon altered astrocytic $\left[\mathrm{Cl}^{-}\right]_{\mathrm{i}}$. Again, for variable astrocytic $\left[\mathrm{Cl}^{-}\right]_{\mathrm{i}}{ }^{-}$ depending on expression levels of NKCC1, KCCs and EAATs-we expect different degrees of cell swelling and glutamate release.

Under physiological conditions, astrocytes utilize $\mathrm{Na}^{+}$and $\mathrm{Cl}^{-}$gradients for secondaryactive GABA [225,226] and glycine uptake [227]. Since GABA and $\mathrm{Cl}^{-}$transport are coupled in a 1:1 stoichiometry, the driving force for GABA uptake will change inversely proportional with $\left[\mathrm{Cl}^{-}\right]_{\mathrm{i}}$, i.e., a twofold higher $\left[\mathrm{Cl}^{-}\right]_{\mathrm{i}}$ will increase the equilibrium concentration of GABA in the ECS by $100 \%$ [228]. Whether such processes play a role in human diseases is currently unclear.

Astroglial $\mathrm{Cl}^{-}$homeostasis thus not only represents a main determinant of volume regulation, but also emerges as an important regulator of synaptic transmission. We are anxiously awaiting a more comprehensive understanding how astrocytes regulate $\left[\mathrm{Cl}^{-}\right]_{\mathrm{i}}$, and how changes in these concentrations are compensated under physiological and pathophysiological conditions. We are used to assume that cellular ion concentrations are fixed values without significant variation between different cell types. $\mathrm{Cl}^{-}$appears to be an exception of this concept. There is marked variability in $\left[\mathrm{Cl}^{-}\right]_{i}$ among different tissues, ranging from values only slightly above passive distribution in muscle $[229,230]$ to $150 \mathrm{mM}$ in glioblastoma cells [231]. Future work will clarify whether there is such variability also between different glia cells in distinct brain areas.

\section{Generation of Cell Swelling and Cerebral Edema}

\subsection{Volume and Water Transport in Animal Cells}

The volume of a cell basically reflects the intracellular amount of water [232], and in most animal cells, cell volume is actively regulated [233]. Because animal cells have non-rigid cell walls that limit the generation of a significant hydrostatic pressure but allow passage of water molecules, the intra- and extracellular osmolarity need to be tightly controlled to maintain cell volume [234-236]. Cell volume is therefore essentially defined by the total amount of osmolytes [237].

The lipid membrane of cells has a very limited permeability for water [238], but water molecules can also cross the membrane through some transporters $[239,240]$ and ion channels [241-243]. In many cells, the transmembrane passage of water is through aquaporin (AQP) channels, mainly expressed in astrocytes $[179,244]$. Central nervous system neurons presumably lack functional AQP, suggesting that their cell volume is 
more resistant to changes in extracellular osmolarity. Indeed, neurons do maintain their cell volume if exposed to short periods $(20 \mathrm{~min})$ of acute osmotic stress, while astrocytes significantly swell [245]. However, if energy is deprived or extracellular $\mathrm{K}^{+}$concentrations are increased, neurons depolarize and swelling does quickly occur, presumably resulting from opening of non-aquaporin water transport pathways [180], including the EAATs and NKCC1 [246,247]. Differences in the cytoskeletal matrix may also be involved in the differential sensitivity to osmotic stress [232].

The major routes for water transport across the membrane of the neuron and astrocyte are shown in Figure 5. Although water is transported via the various energy dependent co-transporters, the main route is via passive transport. The flow of water across the membrane can therefore essentially be described as filtration: movement resulting from a hydrostatic and ionic pressure gradient.
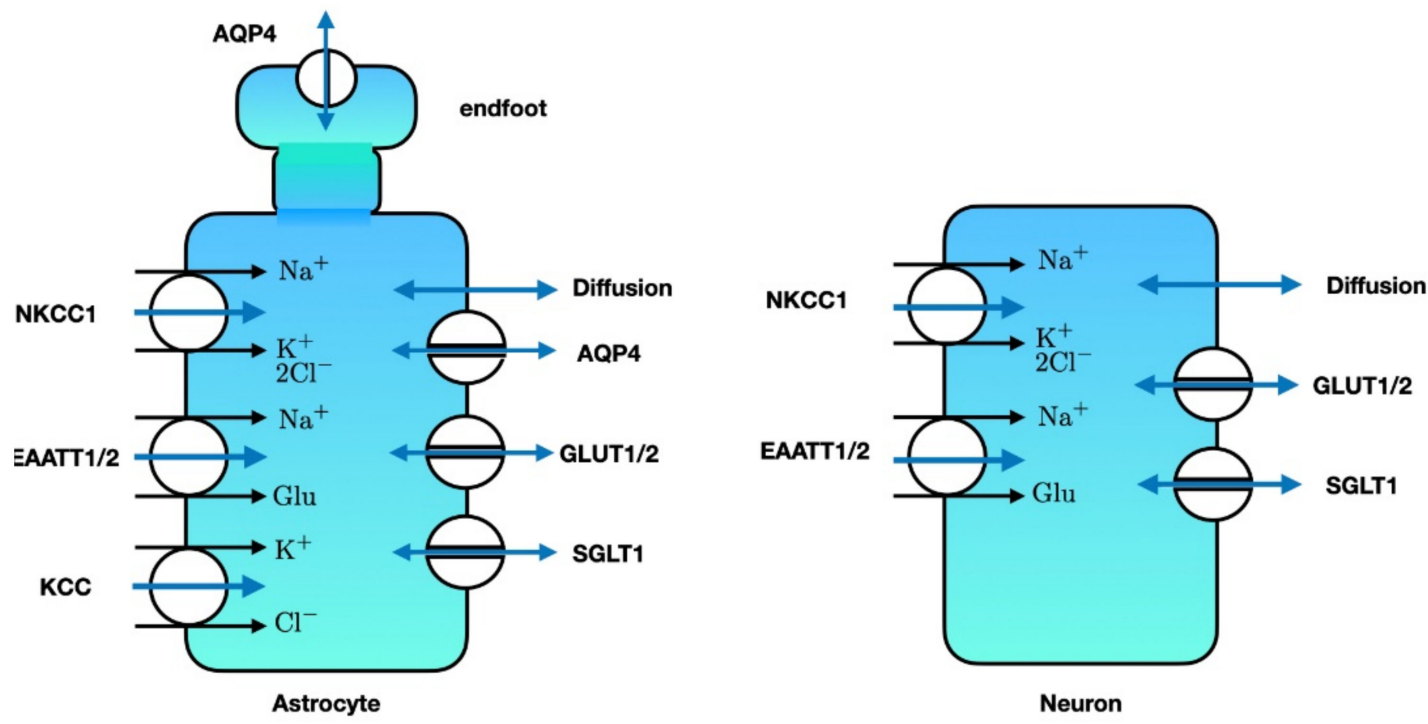

Figure 5. Major transporters and channels that allow water to enter the astrocyte (left) or neuron (right). Single-headed blue arrows denote water co-transport, while double-headed blue arrows denote passive water transport. SGLT: sodium glucose co-transporter. GLUT: glucose transporter. EAAT: excitatory amino acid transporter. NKCC1: sodium-potassium-2 chloride-co transporter. AQP4: aquaporin-4. KCC: potassium-chloride co-transporter. Note that the astrocytic endfeet mainly contain AQP4 for water transport. Illustration adapted from [178,248].

In patients with ischemic stroke, significant osmotic imbalances and changes in membrane potential occur, and cell swelling may follow, depending on the depth and duration of the energy depletion $[16,235,248]$. This increase in cell volume, cytotoxic or cellular edema, does not change the total brain volume, as fluid is essentially moved from the ECS to the intracellular compartments. In several patients, however, the cytotoxic edema is followed by increased water transport across the blood brain barrier (BBB), increasing the total brain volume, causing cerebral edema or brain swelling [248,249]. This process evolves at time scales of hours to days after the primary insult and is a major contributor to secondary brain damage as brain volume is limited by the rigidity of the skull [250]. We will briefly review the fundamental biophysical principles involved in the generation of cell swelling and cerebral edema.

\subsection{Ion Concentrations and Osmolarity at the Gibbs-Donnan Equilibrium}

To understand the direction of ion movement and changes in ion concentrations as a result of energy deprivation, let us assume that all ATP-dependent processes are halted. Cells will then evolve to their thermodynamic equilibrium and each permeant species $\left(\mathrm{Na}^{+}\right.$, 
$\mathrm{K}^{+}$and $\mathrm{Cl}^{-}$) will be in Nernst equilibrium at the same value of the membrane potential, expressed as [251,252]:

$$
\frac{\left[\mathrm{Na}^{+}\right]_{i}}{\left[\mathrm{Na}^{+}\right]_{e}}=\frac{\left[\mathrm{K}^{+}\right]_{i}}{\left[\mathrm{~K}^{+}\right]_{e}}=\frac{\left[\mathrm{Cl}^{-}\right]_{e}}{\left[\mathrm{Cl}^{-}\right]_{i}}
$$

resulting in the equilibrium [246]:

$$
\left(\left[\mathrm{Na}^{+}\right]_{i}+\left[\mathrm{K}^{+}\right]_{i}\right)\left[\mathrm{Cl}^{-}\right]_{i}=\left(\left[\mathrm{Na}^{+}\right]_{e}+\left[\mathrm{K}^{+}\right]_{e}\right)\left[\mathrm{Cl}^{-}\right]_{e}
$$

with $[X]_{i, e}$ the intracellular $(i)$ or extracellular $(e)$ concentration of ion species $X$. The equilibrium potential at $\mathrm{T}=37^{\circ} \mathrm{C}$ is given by the Nernst equation $[252,253]$ :

$$
V_{\mathrm{gd}}=-61 \log _{10} \frac{\left[\mathrm{X}^{+}\right]_{i}}{\left[\mathrm{X}^{+}\right]_{e}} \mathrm{mV}
$$

with $X$ the concentration of $\mathrm{Na}^{+}, \mathrm{K}^{+}$or $\mathrm{Cl}^{-}$.

Further, the sum of all freely moving charges in a solute is zero (electroneutrality) [253]. The intracellular (and, to a lesser extent the extracellular) fluid also contain non-permeable negatively charged macromolecules, with equivalent concentrations $\left[\mathrm{A}^{-}\right]_{i}$, and $\left[\mathrm{A}^{-}\right]_{e}$, respectively [251]. For the intracellular fluid this implies:

$$
\left[\mathrm{Na}^{+}\right]_{i}+\left[\mathrm{K}^{+}\right]_{i}=\left[\mathrm{Cl}^{-}\right]_{i}+\left[\mathrm{A}^{-}\right]_{i}
$$

and for the extracellular compartment we require:

$$
\left[\mathrm{Na}^{+}\right]_{e}+\left[\mathrm{K}^{+}\right]_{e}=\left[\mathrm{Cl}^{-}\right]_{e}+\left[\mathrm{A}^{-}\right]_{e} .
$$

The intracellular $\mathrm{Na}^{+}$at equilibrium can now be expressed as [252]

$$
\left[\mathrm{Na}^{+}\right]_{i}=\left[\mathrm{Na}^{+}\right]_{e} \frac{\left[A^{-}\right]_{i}+\sqrt{\left[A^{-}\right]_{i}^{2}+4 \beta\left(\beta-\left[A^{-}\right]_{e}\right)}}{2 \beta}
$$

with $\beta=\left[\mathrm{Na}^{+}\right]_{e}+\left[\mathrm{K}^{+}\right]_{e}$. All ion concentrations at this equilibrium are thus completely defined by the concentrations of extracellular $\mathrm{Na}^{+}$and $\mathrm{K}^{+}$and the equivalent intracellular and extracellular non-permeable anion concentrations.

For example, setting $\left[\mathrm{Na}^{+}\right]_{e}=140 \mathrm{mM},\left[\mathrm{K}^{+}\right]_{e}=15 \mathrm{mM},\left[\mathrm{A}^{-}\right]_{e}=0 \mathrm{mM}$ and $\left[A^{-}\right]_{i}=125 \mathrm{mM}$, we find that $\left[\mathrm{Na}^{+}\right]_{i}=207 \mathrm{mM},\left[\mathrm{K}^{+}\right]_{i}=22.2 \mathrm{mM},\left[\mathrm{Cl}^{-}\right]_{i}=105 \mathrm{mM},\left[\mathrm{Cl}^{-}\right]_{e}=155 \mathrm{mM}$ and $V_{\mathrm{gd}}=-10.4 \mathrm{mV}$. The non-zero membrane potential is known as the Gibbs-Donnan potential that results from the difference in the equivalent concentrations of the intraand extracellular impermeant ions (cf Equation 6); if the difference would be zero, all ion gradients at equilibrium vanish with corresponding membrane potential $V_{m}=0 \mathrm{mV}$.

We can also estimate the osmotic pressure at this Gibbs-Donnan equilibrium by considering the concentration difference of the non-organic ions, only, and neglect the (much smaller) contribution of the charged organic macromolecules and other, non-charged, solutes. Using the numerical example above, $\Delta c \approx 24.2 \mathrm{mM}$, resulting in an osmotic pressure of $\pi=$ RT $\Delta c=6 \times 10^{4} \mathrm{~Pa}$. As the hydrostatic pressure that neurons and astrocytes can generate (approximately $300 \mathrm{~Pa}$ [251]) is much smaller than the osmotic pressure, the water flux is essentially defined by the osmotic pressure difference [248,251,254].

The presence of both a low intracellular osmolarity and low intracellular $\mathrm{Na}^{+}$in living cells implies that they operate far from their thermodynamic equilibrium. The main mechanism that prevents accumulation of intracellular $\mathrm{Na}^{+}$and-at the same timemaintains a low intracellular osmolarity, is the NKA in the neuronal and astrocytic cell membrane, in combination with their low $\mathrm{Na}^{+}$permeability at the resting membrane potential $[246,248,251]$. 


\subsection{Dynamics of Cell Volume Changes during Metabolic Stress}

During energy deprivation, the number of ions in the extra- and intracellular space will not be constant as cells will accumulate $\mathrm{Na}^{+}$and excrete $\mathrm{K}^{+}$as they will tend towards the Gibbs-Donnan equilibrium. The increase in extracellular $\mathrm{K}^{+}$cannot be fully compensated by astrocytes [103,255-257], as their buffering capacity is limited and compromised during metabolic stress [258] and membrane potentials will decrease. Depending on the depth and duration of the energy deprivation, the excess intracellular $\mathrm{Na}^{+}$is not always compensated with a similar efflux of $\mathrm{K}^{+}$to maintain electroneutrality $[235,254]$ and $\mathrm{Cl}^{-}$influx is needed to maintain electroneutrality. This results in an increase in intracellular osmolarity, and cell swelling is inevitable $[235,248,254,259,260]$.

How fast neurons or astrocytes will swell is a function of the effective water permeability. Astrocytes can very quickly change their volume in response to changes in osmolarity, mainly at their perivascular endfeet where the AQP4 density is largest $[244,261,262]$. For neurons, the permeability for water in physiological conditions is much smaller, and volume changes in response to changes in osmolarity are slower (Andrew et al., 2007). Water permeability can also change by e.g., differences in the activity of NKCC1 [180].

Biophysical models can also further our understanding of the complex interactions between the several processes involved in ion and volume homeostasis $[254,257]$. A detailed model of the tripartite synapse confirms the essential role of glia to maintain ion gradients and cell volume for reliable neurotransmission and also elucidates the relative importance of several energy dependent processes involved in the development cytotoxic edema at different levels and durations of metabolic stress [258].

\subsection{Cerebral Edema}

While cell swelling (cytotoxic edema) expresses redistribution of extracellular water into the intracellular compartment, a net flux of water through the blood brain barrier (BBB) generates cerebral edema $[248,249,263,264]$. This most often results from severe traumatic brain injury, hypoxia or ischemia (Figure 6).
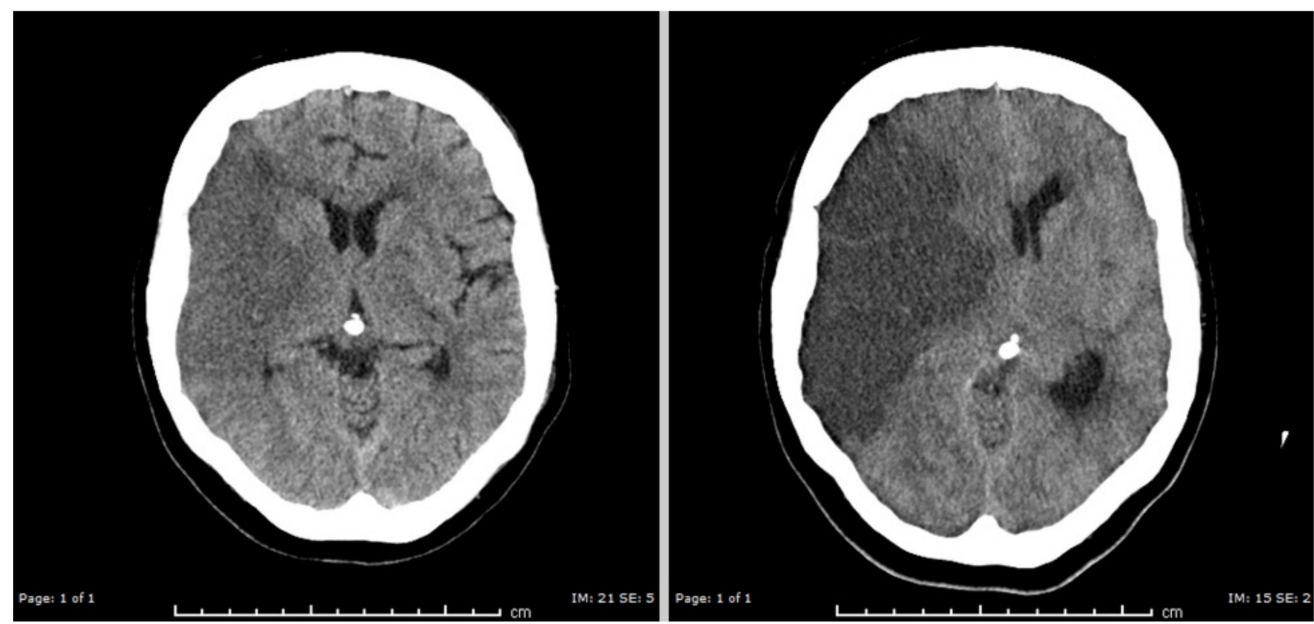

Figure 6. Cerebral edema resulting from an ischemic stroke. Left: head CT with hypodense gray and white matter on the right side of the brain (left in the picture). This essentially reflects cytotoxic cell swelling in the acute phase of the infarction. Right: head CT two days later showing massive cerebral edema of the infarcted tissue, with displacement of brain tissue to the left side. Courtesy of M. Hazewinkel, radiologist Medisch Spectrum Twente. "Reused with permission of Springer, (c) MJAM van Putten [252]".

The BBB is a dedicated barrier between the arterial blood flow to the brain and the brain parenchyma, created by functionally asymmetric endothelial cells (Figure 7). At the luminal side, the endothelial cells contain NKCC1, GLUT1/2 and SGLT1. At the abluminal 
side, the main transporter that co-transports water is KCC. Both endothelial sides also allow water to enter through diffusion.

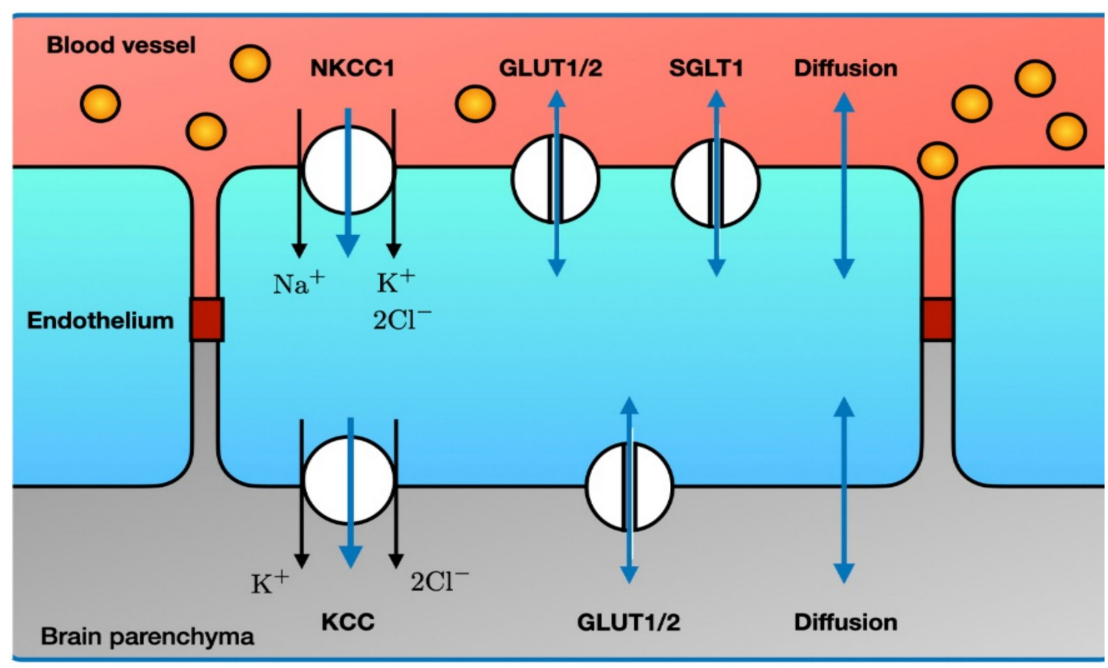

Figure 7. Major routes for influx of water through the blood brain barrier. Single-headed blue arrows denote water co-transport, while double-headed blue arrows denote passive water transport. Note the asymmetry in the various transporters between the luminal and abluminal side. Endothelial tight junctions (dark red) prevent leakage of macromolecules (e.g., albumin, yellow circles) from the capillary blood. The many other ion transporters and ion channels that do not transport water are not shown. Abbreviations: see text. Illustration adapted from [248].

The first phase of water flux through the BBB results from an increase in the $\mathrm{Na}^{+}$gradient between the capillary blood and the ECS: ionic edema, mediated by the endothelial ion channels and transporters. At this stage, the integrity of the BBB is structurally intact [263]. Vasogenic edema results from a disruption in the BBB and extravasation of serum proteins (such as albumin) into the cerebral parenchyma [248,264-266]. These serum proteins will add to the osmotic pressure gradients across the BBB, furthering water movement into the brain parenchyma. In pioneering work by Ito et al. it was shown that in experimental stroke in Mongolian Gerbils cytotoxic edema developed nearly immediately. The onset of vasogenic edema, measured by passage of ${ }^{131} \mathrm{I}$-albumin from blood into the brain, occurred after restoration of blood flow, with peak values at about $20 \mathrm{~h}$ [263]. Return to baseline varied with a maximum duration up to 1 week. Such timescales are also observed in the clinic [250,267]. A major risk resulting from cerebral edema is compression of otherwise healthy brain tissue, resulting in direct mechanical damage and compression of vasculature, causing secondary ischemia (Figure 7).

During disease states, transporter expression can change. For example, total NKCC activity in endothelial cells was reduced in an experimental stroke model [268] and GLUT1 and SGLT1 activity were increased during OGD in endothelial cells co-cultured with astrocytes [269]. It is also reported that NKCC1 activity can increase in stroke, contributing to more excretion of $\mathrm{Na}^{+}, \mathrm{Cl}^{-}$and water across the $\mathrm{BBB}[270,271]$. In mice exposed to permanent focal ischemia, activity of SGLT1 and GLUT1 was increased and inhibition of SGLT1 with phlorizin decreased infarct and edema [269].

\section{Conclusions}

The astrocyte is a multitalented cell. Its functions are essential for $\mathrm{Na}^{+}, \mathrm{K}^{+}$, and $\mathrm{Cl}^{-}$ homeostasis, control of $\mathrm{pH}$ and cell volume which are key to action potential generation and propagation and for reliable neurotransmission at the tripartite synapse. Astrocytic dysfunction, either in isolation or during energy depletion, results in significant reversible and irreversible changes in neural functioning synaptic transmission and water homeostasis. A better understanding of the various (energy dependent) astrocytic functions holds 
large potential to add to identification of novel, targeted treatments to improve recovery of patients with ischemic stroke. This includes targets to limit irreversible cell damage and indirect damage resulting from cerebral edema.

Author Contributions: All authors have contributed to the conceptualization, writing and editing of this work. All authors have read and agreed to the published version of the manuscript.

Funding: This research was funded by the German Research Foundation (DFG), Research Unit FOR 2795 "Synapses under stress" (Ro2327/13-1, 14-1 and FA 301/13-1).

Conflicts of Interest: The authors declare no conflict of interest.

\section{References}

1. Astrup, J.; Siesjö, B.K.; Symon, L. Thresholds in cerebral ischemia-The ischemic penumbra. Stroke 1981, 12, 723-725. [CrossRef]

2. Heiss, W.-D.; Graf, R.; Wienhard, K.; Löttgen, J.; Saito, R.; Fujita, T.; Rosner, G.; Wagner, R. Dynamic Penumbra Demonstrated by Sequential Multitracer PET after Middle Cerebral Artery Occlusion in Cats. Br. J. Pharmacol. 1994, 14, 892-902. [CrossRef]

3. Berkhemer, O.A.; Fransen, P.S.S.; Beumer, D.; Berg, L.A.V.D.; Lingsma, H.F.; Yoo, A.J.; Schonewille, W.J.; Vos, J.A.; Nederkoorn, P.J.; Wermer, M.J.H.; et al. A Randomized Trial of Intraarterial Treatment for Acute Ischemic Stroke. New Engl. J. Med. 2015, 372, 11-20. [CrossRef]

4. Dirnagl, U.; Iadecola, C.; Moskowitz, M.A. Pathobiology of ischaemic stroke: An integrated view. Trends Neurosci. 1999, 22, 391-397. [CrossRef]

5. Bandera, E.; Botteri, M.; Minelli, C.; Sutton, A.; Abrams, K.R.; Latronico, N. Cerebral blood flow threshold of ischemic penumbra and infarct core in acute ischemic stroke: A systematic review. Stroke 2006, 37, 1334-1339. [CrossRef]

6. Moskowitz, M.A.; Lo, E.H.; Iadecola, C. The Science of Stroke: Mechanisms in Search of Treatments. Neuron 2010, 67, 181-198. [CrossRef] [PubMed]

7. Bolay, H.; Güsoy-Özdemir, Y.; Sara, Y.; Onur, R.; Can, A.; Dalkara, T. Persistent Defect in Transmitter Release and Synapsin Phosphorylation in Cerebral Cortex After Transient Moderate Ischemic Injury. Stroke 2002, 33, 1369-1375. [CrossRef] [PubMed]

8. Le Feber, J.; Pavlidou, S.T.; Erkamp, N.; Van Putten, M.J.A.M.; Hofmeijer, J. Progression of Neuronal Damage in an In Vitro Model of the Ischemic Penumbra. PLoS ONE 2016, 11, e0147231. [CrossRef]

9. Kim, B.J.; Menon, B.K.; Kim, J.Y.; Shin, D.-W.; Baik, S.H.; Jung, C.; Han, M.-K.; Demchuk, A.; Bae, H.-J. Endovascular Treatment After Stroke Due to Large Vessel Occlusion for Patients Presenting Very Late from Time Last Known Well. JAMA Neurol. 2021, 78, 21. [CrossRef] [PubMed]

10. Lai, T.W.; Zhang, S.; Wang, Y.T. Excitotoxicity and stroke: Identifying novel targets for neuroprotection. Prog. Neurobiol. 2014, 115, 157-188. [CrossRef]

11. Kristián, T.; Siesjö, B.K. Calcium in Ischemic Cell Death. Stroke 1998, 29, 705-718. [CrossRef]

12. Choi, D.W. Excitotoxicity: Still Hammering the Ischemic Brain in 2020. Front. Neurosci. 2020, 14, 579953. [CrossRef] [PubMed]

13. Zandt, B.-J.; Haken, B.T.; Van Putten, M.J.A.M. Diffusing Substances during Spreading Depolarization: Analytical Expressions for Propagation Speed, Triggering, and Concentration Time Courses. J. Neurosci. 2013, 33, 5915-5923. [CrossRef]

14. Ayata, C.; Lauritzen, M. Spreading Depression, Spreading Depolarizations, and the Cerebral Vasculature. Physiol. Rev. 2015, 95, 953-993. [CrossRef]

15. Dreier, J.P. The role of spreading depression, spreading depolarization and spreading ischemia in neurological disease. Nat. Med. 2011, 17, 439-447. [CrossRef]

16. Hofmeijer, J.; van Putten, M.J.A.M. Ischemic cerebral damage: An appraisal of synaptic failure. Stroke 2012, 43, 607-615. [CrossRef]

17. Hartings, J.A.; Shuttleworth, C.W.; Kirov, S.A.; Ayata, C.; Hinzman, J.M.; Foreman, B.; Andrew, R.D.; Boutelle, M.G.; Brennan, K.C.; Carlson, A.P.; et al. The continuum of spreading depolarizations in acute cortical lesion development: Examining Leão's legacy. Br. J. Pharmacol. 2016, 37, 1571-1594. [CrossRef] [PubMed]

18. Del Zoppo, G.J.; Sharp, F.R.; Heiss, W.-D.; Albers, G.W. Heterogeneity in the penumbra. Br. J. Pharmacol. 2011, $31,1836-1851$. [CrossRef] [PubMed]

19. Walz, W. Role of astrocytes in the clearance of excess extracellular potassium. Neurochem. Int. 2000, 36, 291-300. [CrossRef]

20. Danbolt, N.C. Glutamate uptake. Prog. Neurobiol. 2001, 65, 1-105. [CrossRef]

21. Zeng, X.-N.; Sun, X.-L.; Gao, L.; Fan, Y.; Ding, J.-H.; Hu, G. Aquaporin-4 deficiency down-regulates glutamate uptake and GLT-1 expression in astrocytes. Mol. Cell. Neurosci. 2007, 34, 34-39. [CrossRef]

22. Bélanger, M.; Allaman, I.; Magistretti, P.J. Brain Energy Metabolism: Focus on Astrocyte-Neuron Metabolic Cooperation. Cell Metab. 2011, 14, 724-738. [CrossRef] [PubMed]

23. Dong, Y.; Benveniste, E.N. Immune function of astrocytes. Glia 2001, 36, 180-190. [CrossRef]

24. Verkhratsky, A.; Nedergaard, M. Physiology of Astroglia. Physiol. Rev. 2018, 98, 239-389. [CrossRef] [PubMed]

25. De Bock, M.; Van Haver, V.; Vandenbroucke, R.E.; Decrock, E.; Wang, N.; Leybaert, L. Into rather unexplored ter-rain-transcellular transport across the blood-brain barrier. Glia 2016, 64, 1097-1123. [CrossRef] [PubMed]

26. Barreto, G.; White, R.E.; Ouyang, Y.; Xu, L.; Giffard, R.G. Astrocytes: Targets for Neuroprotection in Stroke. Central Nerv. Syst. Agents Med. Chem. 2011, 11, 164-173. [CrossRef] [PubMed] 
27. Annunziato, L.; Boscia, F.; Pignataro, G. Ionic Transporter Activity in Astrocytes, Microglia, and Oligodendrocytes During Brain Ischemia. Br. J. Pharmacol. 2013, 33, 969-982. [CrossRef] [PubMed]

28. Nedergaard, M.; Dirnagl, U. Role of glial cells in cerebral ischemia. Glia 2005, 50, 281-286. [CrossRef] [PubMed]

29. Koizumi, S.; Hirayama, Y.; Morizawa, Y.M. New roles of reactive astrocytes in the brain; an organizer of cerebral ischemia. Neurochem. Int. 2018, 119, 107-114. [CrossRef] [PubMed]

30. Chen, Y.; Swanson, R.A. Astrocytes and brain injury. J. Cereb. Blood Flow Metab. 2003, 23, 137-149. [CrossRef] [PubMed]

31. Choudhury, G.R.; Ding, S. Reactive astrocytes and therapeutic potential in focal ischemic stroke. Neurobiol. Dis. 2016, 85, 234-244. [CrossRef] [PubMed]

32. Morizawa, Y.M.; Hirayama, Y.; Ohno, N.; Shibata, S.; Shigetomi, E.; Sui, Y.; Nabekura, J.; Sato, K.; Okajima, F.; Take-bayashi, H.; et al. Reactive astrocytes function as phagocytes after brain ischemia via ABCA1-mediated pathway. Nat. Commun. 2017, 8, 28. [CrossRef]

33. Mink, J.W.; Blumenschine, R.J.; Adams, D.B. Ratio of central nervous system to body metabolism in vertebrates: Its constancy and functional basis. Am. J. Physiol. Integr. Comp. Physiol. 1981, 241, R203-R212. [CrossRef] [PubMed]

34. Harris, J.J.; Jolivet, R.; Attwell, D. Synaptic Energy Use and Supply. Neuron 2012, 75, 762-777. [CrossRef] [PubMed]

35. Engl, E.; Attwell, D. Non-signalling energy use in the brain. J. Physiol. 2015, 593, 3417-3429. [CrossRef] [PubMed]

36. Erecińska, M.; Silver, I.A. Ions and energy in mammalian brain. Prog. Neurobiol. 1994, 43, 37-71. [CrossRef]

37. Somjen, G.G. Ions in the Brain: Normal Function, Seizures, and Stroke; Oxford University Press: New York, NY, USA, 2004.

38. Astrup, J.; Sørensen, P.M.; Sørensen, H.R. Oxygen and glucose consumption related to $\mathrm{Na}^{+}-\mathrm{K}^{+}$transport in canine brain. Stroke 1981, 12, 726-730. [CrossRef]

39. Howarth, C.; Gleeson, P.; Attwell, D. Updated Energy Budgets for Neural Computation in the Neocortex and Cerebellum. Br. J. Pharmacol. 2012, 32, 1222-1232. [CrossRef]

40. Lennie, P. The Cost of Cortical Computation. Curr. Biol. 2003, 13, 493-497. [CrossRef]

41. Sweadner, K.J. Isozymes of the $\mathrm{Na}^{+} / \mathrm{K}^{+}$-ATPase. Biochim. Biophys. Acta. 1989, 988, 185-220. [CrossRef]

42. Kaplan, J.H. Biochemistry of Na, K-ATPase. Annu. Rev. Biochem. 2002, 71, 511-535. [CrossRef]

43. Clapham, D.E. Calcium Signaling. Cell 2007, 131, 1047-1058. [CrossRef] [PubMed]

44. Cotter, K.; Stransky, L.; McGuire, C.; Forgac, M. Recent Insights into the Structure, Regulation, and Function of the V-ATPases. Trends Biochem. Sci. 2015, 40, 611-622. [CrossRef] [PubMed]

45. Jang, S.; Nelson, J.C.; Bend, E.G.; Rodríguez-Laureano, L.; Tueros, F.G.; Cartagenova, L.; Underwood, K.; Jorgensen, E.M.; Colón-Ramos, D.A. Glycolytic Enzymes Localize to Synapses under Energy Stress to Support Synaptic Function. Neuron 2016, 90, 278-291. [CrossRef]

46. Sobieski, C.; Fitzpatrick, M.J.; Mennerick, S.J. Differential Presynaptic ATP Supply for Basal and High-Demand Transmission. J. Neurosci. 2017, 37, 1888-1899. [CrossRef]

47. Clausen, M.V.; Hilbers, F.; Poulsen, H. The Structure and Function of the Na, K-ATPase Isoforms in Health and Disease. Front. Physiol. 2017, 8, 371. [CrossRef]

48. Sweadner, K. Sodium, Potassium-Adenosine Triphosphatase and Its Isoforms; Neuroglia, R.B., Kettenmann, H., Eds.; Oxford University Press: New York, NY, USA, 1995; pp. 259-272.

49. Verkhratsky, A.; Rose, C.R. Na ${ }^{+}$-dependent transporters: The backbone of astroglial homeostatic function. Cell Calcium 2020, 85, 102136. [CrossRef] [PubMed]

50. Rossi, D.J.; Oshima, T.; Attwell, D. Glutamate release in severe brain ischaemia is mainly by reversed uptake. Nat. Cell Biol. 2000, 403, 316-321. [CrossRef]

51. Rose, C.R.; Ziemens, D.; Verkhratsky, A. On the special role of NCX in astrocytes: Translating $\mathrm{Na}^{+}$-transients into intracellular $\mathrm{Ca}^{2+}$ signals. Cell Calcium 2020, 86, 102154. [CrossRef]

52. Tønnesen, J.; Inavalli, V.K.; Nägerl, U.V. Super-Resolution Imaging of the Extracellular Space in Living Brain Tissue. Cell 2018, 172, 1108-1121e.15. [CrossRef]

53. Grosche, J.; Kettenmann, H.; Reichenbach, A. Bergmann glial cells form distinct morphological structures to interact with cerebellar neurons. J. Neurosci. Res. 2002, 68, 138-149. [CrossRef]

54. Khakh, B.S. Astrocyte-Neuron Interactions in the Striatum: Insights on Identity, Form, and Function. Trends Neurosci. 2019, 42, 617-630. [CrossRef] [PubMed]

55. Allen, N.J.; Eroglu, C. Cell Biology of Astrocyte-Synapse Interactions. Neuron 2017, 96, 697-708. [CrossRef]

56. Brown, A.M.; Ransom, B.R. Astrocyte glycogen and brain energy metabolism. Glia 2007, 55, 1263-1271. [CrossRef]

57. Hertz, L.; Xu, J.; Song, D.; Du, T.; Li, B.; Yan, E.; Peng, L. Astrocytic glycogenolysis: Mechanisms and functions. Metab. Brain Dis. 2014, 30, 317-333. [CrossRef] [PubMed]

58. Mathiisen, T.M.; Lehre, K.P.; Danbolt, N.C.; Ottersen, O.P. The perivascular astroglial sheath provides a complete covering of the brain microvessels: An electron microscopic 3D reconstruction. Glia 2010, 58, 1094-1103. [CrossRef]

59. Alberini, C.M.; Cruz, E.; Descalzi, G.; Bessières, B.; Gao, V. Astrocyte glycogen and lactate: New insights into learning and memory mechanisms. Glia 2018, 66, 1244-1262. [CrossRef] [PubMed]

60. Bak, L.K.; Walls, A.B.; Schousboe, A.; Waagepetersen, H.S. Astrocytic glycogen metabolism in the healthy and diseased brain. J. Biol. Chem. 2018, 293, 7108-7116. [CrossRef]

61. Pellerin, L.; Magistretti, P.J. Sweet sixteen for ANLS. J. Cereb. Blood Flow Metab. 2012, 32, 1152-1166. [CrossRef] 
62. Chatton, J.-Y.; Magistretti, P.J.; Barros, L.F. Sodium signaling and astrocyte energy metabolism. Glia 2016, 64, 1667-1676. [CrossRef] [PubMed]

63. Lerchundi, R.; Huang, N.; Rose, C.R. Quantitative Imaging of Changes in Astrocytic and Neuronal Adenosine Tri-phosphate Using Two Different Variants of ATeam. Front Cell Neurosci. 2020, 14, 80. [CrossRef]

64. Rose, C.; Chatton, J.-Y. Astrocyte sodium signaling and neuro-metabolic coupling in the brain. Neuroscience 2016, 323, 121-134. [CrossRef]

65. Barros, L.F. Metabolic signaling by lactate in the brain. Trends Neurosci. 2013, 36, 396-404. [CrossRef] [PubMed]

66. Magistretti, P.J.; Allaman, I. Lactate in the brain: From metabolic end-product to signalling molecule. Nat. Rev. Neurosci. 2018, 19, 235-249. [CrossRef] [PubMed]

67. Fünfschilling, U.; Supplie, L.M.; Mahad, D.; Boretius, S.; Saab, A.S.; Edgar, J.; Brinkmann, B.G.; Kassmann, C.M.; Tzvetanova, I.D.; Möbius, W.; et al. Glycolytic oligodendrocytes maintain myelin and long-term axonal integrity. Nature 2012, 485, 517-521. [CrossRef]

68. Hirrlinger, J.; Nave, K.-A. Adapting brain metabolism to myelination and long-range signal transduction. Glia 2014, 62, 1749-1761. [CrossRef] [PubMed]

69. Barros, L.F.; Weber, B. CrossTalk proposal: An important astrocyte-to-neuron lactate shuttle couples neuronal activity to glucose utilisation in the brain. J. Physiol. 2018, 596, 347-350. [CrossRef] [PubMed]

70. Sickmann, H.M.; Walls, A.B.; Schousboe, A.; Bouman, S.D.; Waagepetersen, H.S. Functional significance of brain gly-cogen in sustaining glutamatergic neurotransmission. J. Neurochem. 2009, 109, 80-86. [CrossRef] [PubMed]

71. Bak, L.K.; Walls, A.B. CrossTalk opposing view: Lack of evidence supporting an astrocyte-to-neuron lactate shuttle coupling neuronal activity to glucose utilisation in the brain. J. Physiol. 2018, 596, 351-353. [CrossRef]

72. Dienel, G.A. Brain Glucose Metabolism: Integration of Energetics with Function. Physiol. Rev. 2019, 99, 949-1045. [CrossRef]

73. Rothman, D.L.; Dienel, G.A. Development of a Model to Test Whether Glycogenolysis Can Support Astrocytic Energy Demands of $\mathrm{Na}^{+}, \mathrm{K}^{+}$-ATPase and Glutamate-Glutamine Cycling, Sparing an Equivalent Amount of Glucose for Neurons. Adv. Neurobiol. 2019, 23, 385-433. [CrossRef]

74. Verkhratsky, A.; Untiet, V.; Rose, C.R. Ionic signalling in astroglia beyond calcium. J. Physiol. 2020, 598, 1655-1670. [CrossRef] [PubMed]

75. Ventura, R.; Harris, K.M. Three-Dimensional Relationships between Hippocampal Synapses and Astrocytes. J. Neurosci. 1999, 19, 6897-6906. [CrossRef]

76. Grosche, J.; Matyash, V.; Möller, T.; Verkhratsky, A.; Reichenbach, A.; Kettenmann, H. Microdomains for neuron-glia interaction: Parallel fiber signaling to Bergmann glial cells. Nat. Neurosci. 1999, 2, 139-143. [CrossRef] [PubMed]

77. Kofuji, P.; Newman, E. Regulation of potassium by glial cells in the central nervous system. In Astrocytes in (Patho)Physiology of the Nervous System; Parpura, V., Haydon, P., Eds.; Springer: Berlin/Heidelberg, Germany, 2009; pp. 151-175.

78. Heinemann, U.; Lux, H.D. Ceiling of stimulus induced rises in extracellular potassium concentration in the cerebral cortex of cat. Brain Res. 1977, 120, 231-249. [CrossRef]

79. Connors, B.; Ransom, B.; Kunis, D.; Gutnick, M. Activity-dependent $\mathrm{K}^{+}$accumulation in the developing rat optic nerve. Sci. 1982, 216, 1341-1343. [CrossRef]

80. Rasmussen, R.; O’Donnell, J.; Ding, F.; Nedergaard, M. Interstitial ions: A key regulator of state-dependent neural activity? Prog. Neurobiol. 2020, 193, 101802. [CrossRef]

81. Hertz, L.; Song, D.; Xu, J.; Peng, L.; Gibbs, M.E. Role of the Astrocytic Na ${ }^{+}, \mathrm{K}^{+}$-ATPase in $\mathrm{K}^{+}$Homeostasis in Brain: $\mathrm{K}^{+} \mathrm{Uptake}$ Signaling Pathways and Substrate Utilization. Neurochem. Res. 2015, 40, 2505-2516. [CrossRef] [PubMed]

82. Larsen, B.R.; Stoica, A.; Macaulay, N. Managing Brain Extracellular $\mathrm{K}^{+}$during Neuronal Activity: The Physiological Role of the $\mathrm{Na}^{+} / \mathrm{K}^{+}$-ATPase Subunit Isoforms. Front. Physiol. 2016, 7, 141. [CrossRef] [PubMed]

83. Karus, C.; Mondragão, M.A.; Ziemens, D.; Rose, C.R. Astrocytes restrict discharge duration and neuronal sodium loads during recurrent network activity. Glia 2015, 63, 936-957. [CrossRef] [PubMed]

84. Rose, C.R.; Ransom, B.R. Intracellular sodium homeostasis in rat hippocampal astrocytes. J. Physiol. 1996, 491, 291-305. [CrossRef]

85. Rose, C.R.; Ransom, B.R. Regulation of intracellular sodium in cultured rat hippocampal neurones. J. Physiol. 1997, 499, 573-587. [CrossRef] [PubMed]

86. Steinhäuser, C.; Seifert, G.; Bedner, P. Astrocyte dysfunction in temporal lobe epilepsy: $\mathrm{K}^{+}$channels and gap junction coupling. Glia 2012, 60, 1192-1202. [CrossRef] [PubMed]

87. Anderson, C.M.; Swanson, R.A. Astrocyte glutamate transport: Review of properties, regulation, and physiological functions. Glia 2000, 32, 1-14. [CrossRef]

88. Maragakis, N.J.; Rothstein, J.D. Glutamate transporters: Animal models to neurologic disease. Neurobiol. Dis. 2004, 15, 461-473. [CrossRef]

89. Hübel, N.; Hosseini-Zare, M.S.; Ziburkus, J.; Ullah, G. The role of glutamate in neuronal ion homeostasis: A case study of spreading depolarization. PLoS Comput. Biol. 2017, 13, e1005804. [CrossRef]

90. Schousboe, A.; Scafidi, S.; Bak, L.K.; Waagepetersen, H.S.; McKenna, M.C. Glutamate Metabolism in the Brain Focusing on Astrocytes. Adv. Neurobiol. 2014, 11, 13-30. [CrossRef]

91. Sonnewald, U. Glutamate synthesis has to be matched by its degradation—where do all the carbons go? J. Neurochem. 2014, 131, 399-406. [CrossRef] 
92. Panatier, A.; Robitaille, R. Astrocytic mGluR5 and the tripartite synapse. Neuroscience 2016, 323, 29-34. [CrossRef] [PubMed]

93. Sun, W.; McConnell, E.; Pare, J.F.; Xu, Q.; Chen, M.; Peng, W.; Lovatt, D.; Han, X.; Smith, Y.; Nedergaard, M. Gluta-mate-dependent neuroglial calcium signaling differs between young and adult brain. Science 2013, 339, 197-200. [CrossRef]

94. Volterra, A.; Liaudet, N.; Savtchouk, I. Astrocyte $\mathrm{Ca}^{2+}$ signalling: An unexpected complexity. Nat. Rev. Neurosci. 2014, 15, 327-335. [CrossRef] [PubMed]

95. Araque, A.; Parpura, V.; Sanzgiri, R.P.; Haydon, P.G. Tripartite synapses: Glia, the unacknowledged partner. Trends Neurosci. 1999, 22, 208-215. [CrossRef]

96. Halassa, M.M.; Fellin, T.; Haydon, P.G. The tripartite synapse: Roles for gliotransmission in health and disease. Trends Mol. Med. 2007, 13, 54-63. [CrossRef]

97. Araque, A.; Carmignoto, G.; Haydon, P.G.; Oliet, S.H.; Robitaille, R.; Volterra, A. Gliotransmitters Travel in Time and Space. Neuron 2014, 81, 728-739. [CrossRef]

98. Fiacco, T.A.; McCarthy, K.D. Multiple Lines of Evidence Indicate That Gliotransmission Does Not Occur under Phys-iological Conditions. J. Neurosci. 2018, 38, 3-13. [CrossRef]

99. Agulhon, C.; Petravicz, J.; McMullen, A.B.; Sweger, E.J.; Minton, S.K.; Taves, S.R.; Casper, K.B.; Fiacco, T.A.; McCarthy, K.D. What Is the Role of Astrocyte Calcium in Neurophysiology? Neuron 2008, 59, 932-946. [CrossRef] [PubMed]

100. Bazargani, N.; Attwell, D. Astrocyte calcium signaling: The third wave. Nat. Neurosci. 2016, 19, 182-189. [CrossRef] [PubMed]

101. Papouin, T.; Dunphy, J.; Tolman, M.; Foley, J.C.; Haydon, P.G. Astrocytic control of synaptic function. Philos. Trans. R. Soc. B Biol. Sci. 2017, 372, 20160154. [CrossRef]

102. Rose, C.R.; Karus, C. Two sides of the same coin: Sodium homeostasis and signaling in astrocytes under physiological and pathophysiological conditions. Glia 2013, 61, 1191-1205. [CrossRef] [PubMed]

103. MacAulay, N. Molecular mechanisms of $\mathrm{K}^{+}$clearance and extracellular space shrinkage-Glia cells as the stars. Glia 2020, 68, 2192-2211. [CrossRef]

104. Theparambil, S.M.; Naoshin, Z.; Thyssen, A.; Deitmer, J.W. Reversed electrogenic sodium bicarbonate cotransporter 1 is the major acid loader during recovery from cytosolic alkalosis in mouse cortical astrocytes. J. Physiol. 2015, 593, 3533-3547. [CrossRef]

105. Deitmer, J.W.; Rose, C.R. REMOVED: Ion changes and signalling in perisynaptic glia. Brain Res. 2009, 63, 113-129. [CrossRef] [PubMed]

106. Scimemi, A. Structure, function, and plasticity of GABA transporters. Front. Cell. Neurosci. 2014, 8, 161. [CrossRef]

107. Schousboe, A.; Wellendorph, P.; Frølund, B.; Clausen, R.P.; Krogsgaard-Larsen, P. Astrocytic GABA Transporters: Pharmacological Properties and Targets for Antiepileptic Drugs. Adv. Neurobiol. 2017, 16, 283-296. [CrossRef] [PubMed]

108. Kirischuk, S.; Parpura, V.; Verkhratsky, A. Sodium dynamics: Another key to astroglial excitability? Trends Neurosci. 2012, 35, 497-506. [CrossRef]

109. Felix, L.; Delekate, A.; Petzold, G.C.; Rose, C.R. Sodium Fluctuations in Astroglia and Their Potential Impact on As-trocyte Function. Front Physiol. 2020, 11, 871. [CrossRef] [PubMed]

110. Langer, J.; Gerkau, N.J.; Derouiche, A.; Kleinhans, C.; Moshrefi-Ravasdjani, B.; Fredrich, M.; Kafitz, K.W.; Seifert, G.; Steinhäuser, C.; Rose, C.R. Rapid sodium signaling couples glutamate uptake to breakdown of ATP in perivascular astrocyte endfeet. Glia 2017, 65, 293-308. [CrossRef]

111. Bennay, M.; Langer, J.; Meier, S.D.; Kafitz, K.W.; Rose, C.R. Sodium signals in cerebellar Purkinje neurons and Bergmann glial cells evoked by glutamatergic synaptic transmission. Glia 2008, 56, 1138-1149. [CrossRef] [PubMed]

112. Langer, J.; Rose, C.R. Synaptically induced sodium signals in hippocampal astrocytes in situ. J. Physiol. 2009, 587, 5859-5877. [CrossRef] [PubMed]

113. Moshrefi-Ravasdjani, B.; Ziemens, D.; Pape, N.; Färfers, M.; Rose, C.R. Action Potential Firing Induces Sodium Tran-sients in Macroglial Cells of the Mouse Corpus Callosum. Neuroglia 2018, 1, 9. [CrossRef]

114. Ziemens, D.; Oschmann, F.; Gerkau, N.J.; Rose, C.R. Heterogeneity of Activity-Induced Sodium Transients between Astrocytes of the Mouse Hippocampus and Neocortex: Mechanisms and Consequences. J. Neurosci. 2019, 39, 2620-2634. [CrossRef]

115. Langer, J.; Stephan, J.; Theis, M.; Rose, C.R. Gap junctions mediate intercellular spread of sodium between hippocampal astrocytes in situ. Glia 2011, 60, 239-252. [CrossRef] [PubMed]

116. Augustin, V.; Bold, C.; Wadle, S.L.; Langer, J.; Jabs, R.; Philippot, C.; Weingarten, D.J.; Rose, C.R.; Steinhäuser, C.; Stephan, J. Functional anisotropic panglial networks in the lateral superior olive. Glia 2016, 64, 1892-1911. [CrossRef] [PubMed]

117. Moshrefi-Ravasdjani, B.; Hammel, E.L.; Kafitz, K.W.; Rose, C.R. Astrocyte Sodium Signalling and Panglial Spread of Sodium Signals in Brain White Matter. Neurochem. Res. 2017, 42, 2505-2518. [CrossRef]

118. Rose, C.R.; Waxman, S.G.; Ransom, B.R. Effects of Glucose Deprivation, Chemical Hypoxia, and Simulated Ischemia on $\mathrm{Na}^{+}$Homeostasis in Rat Spinal Cord Astrocytes. J. Neurosci. 1998, 18, 3554-3562. [CrossRef] [PubMed]

119. Gerkau, N.J.; Rakers, C.; Petzold, G.C.; Rose, C.R. Differential effects of energy deprivation on intracellular sodium homeostasis in neurons and astrocytes. J. Neurosci. Res. 2017, 95, 2275-2285. [CrossRef] [PubMed]

120. Hansen, A.J. Effect of anoxia on ion distribution in the brain. Physiol. Rev. 1985, 65, 101-148. [CrossRef]

121. Longuemare, M.C.; Rose, C.R.; Farrell, K.; Ransom, B.R.; Waxman, S.G.; Swanson, R.A. K(+)-induced reversal of as-trocyte glutamate uptake is limited by compensatory changes in intracellular $\mathrm{Na}^{+}$. Neuroscience 1999, 93, 285-292. [CrossRef]

122. Silver, I.A.; Deas, J.; Erecińska, M. Ion homeostasis in brain cells: Differences in intracellular ion responses to energy limitation between cultured neurons and glial cells. Neuroscience 1997, 78, 589-601. [CrossRef] 
123. Kintner, D.B.; Look, A.; Shull, G.E.; Sun, D. Stimulation of astrocyte $\mathrm{Na}^{+} / \mathrm{H}^{+}$exchange activity in response to in vitro ischemia depends in part on activation of ERK1/2. Am. J. Physiol. Cell Physiol. 2005, 289, C934-C945. [CrossRef] [PubMed]

124. Gerkau, N.J.; Rakers, C.; Durry, S.; Petzold, G.C.; Rose, C.R. Reverse NCX Attenuates Cellular Sodium Loading in Metabolically Compromised Cortex. Cereb. Cortex 2017, 28, 4264-4280. [CrossRef]

125. Rossi, D.J.; Brady, J.D.; Mohr, C. Astrocyte metabolism and signaling during brain ischemia. Nat. Neurosci. 2007, 10, 1377-1386. [CrossRef] [PubMed]

126. Fern, R. Ischemic Tolerance in Pre-Myelinated White Matter: The Role of Astrocyte Glycogen in Brain Pathology. Br. J. Pharmacol. 2015, 35, 951-958. [CrossRef] [PubMed]

127. Swanson, R.A.; Choi, D.W. Glial Glycogen Stores Affect Neuronal Survival during Glucose Deprivation in vitro. Br. J. Pharmacol. 1993, 13, 162-169. [CrossRef] [PubMed]

128. Hertz, L.; Dienel, G.A. Lactate transport and transporters: General principles and functional roles in brain cells. J. Neurosci. Res. 2005, 79, 11-18. [CrossRef] [PubMed]

129. Müller, M.; Somjen, G.G. $\mathrm{Na}^{+}$and $\mathrm{K}^{+}$Concentrations, Extra- and Intracellular Voltages, and the Effect of TTX in Hypoxic Rat Hippocampal Slices. J. Neurophysiol. 2000, 83, 735-745. [CrossRef]

130. Xie, M.; Wang, W.; Kimelberg, H.K.; Zhou, M. Oxygen and Glucose Deprivation-Induced Changes in Astrocyte Membrane Potential and Their Underlying Mechanisms in Acute Rat Hippocampal Slices. Br. J. Pharmacol. 2007, 28, 456-467. [CrossRef] [PubMed]

131. Du, Y.; Wang, W.; Lutton, A.D.; Kiyoshi, C.M.; Ma, B.; Taylor, A.T.; Olesik, J.W.; McTigue, D.M.; Askwith, C.C.; Zhou, M. Dissipation of transmembrane potassium gradient is the main cause of cerebral ischemia-induced depolarization in astrocytes and neurons. Exp. Neurol. 2018, 303, 1-11. [CrossRef]

132. Fonnum, F.; Johnsen, A.; Hassel, B. Use of fluorocitrate and fluoroacetate in the study of brain metabolism. Glia 1997, 21, 106-113. [CrossRef]

133. Szatkowski, M.; Attwell, D. Triggering and execution of neuronal death in brain ischaemia: Two phases of glutamate release by different mechanisms. Trends Neurosci. 1994, 17, 359-365. [CrossRef]

134. Pietrobon, D.; Moskowitz, M.A. Chaos and commotion in the wake of cortical spreading depression and spreading depolarizations. Nat. Rev. Neurosci. 2014, 15, 379-393. [CrossRef]

135. Maragakis, N.J.; Rothstein, J.D. Glutamate Transporters in Neurologic Disease. Arch. Neurol. 2001, 58, 365-370. [CrossRef]

136. Aizawa, H.; Sun, W.; Sugiyama, K.; Itou, Y.; Aida, T.; Cui, W.; Toyoda, S.; Terai, H.; Yanagisawa, M.; Tanaka, K. Glial glutamate transporter GLT -1 determines susceptibility to spreading depression in the mouse cerebral cortex. Glia 2020, 68, $2631-2642$. [CrossRef] [PubMed]

137. Matute, C.; Domercq, M.; Gomez, M.V.S. Glutamate-mediated glial injury: Mechanisms and clinical importance. Glia 2006, 53, 212-224. [CrossRef]

138. Savtchouk, I.; Volterra, A. Gliotransmission: Beyond Black-and-White. J. Neurosci. 2018, 38, 14-25. [CrossRef]

139. Vardjan, N.; Parpura, V.; Zorec, R. Loose excitation-secretion coupling in astrocytes. Glia 2016, 64, 655-667. [CrossRef] [PubMed]

140. Rakers, C.; Petzold, G.C. Astrocytic calcium release mediates peri-infarct depolarizations in a rodent stroke model. J. Clin. Investig. 2016, 127, 511-516. [CrossRef]

141. Boscia, F.; Begum, G.; Pignataro, G.; Sirabella, R.; Cuomo, O.; Casamassa, A.; Sun, D.; Annunziato, L. Glial Na ${ }^{+}$-dependent ion transporters in pathophysiological conditions. Glia 2016, 64, 1677-1697. [CrossRef]

142. Fern, R.F.; Matute, C.; Stys, P.K. White matter injury: Ischemic and nonischemic. Glia 2014, 62, 1780-1789. [CrossRef] [PubMed]

143. Song, S.; Luo, L.; Sun, B.; Sun, D. Roles of glial ion transporters in brain diseases. Glia 2020, 68, 472-494. [CrossRef]

144. Coles, J.A.; Schneider-Picard, G. Increase in glial intracellular $\mathrm{K}^{+}$in drone retina caused by photostimulation but not mediated by an increase in extracellular $\mathrm{K}^{+}$. Glia 1989, 2, 213-222. [CrossRef]

145. Ballanyi, K.; Grafe, P.; Bruggencate, G.T. Ion activities and potassium uptake mechanisms of glial cells in guinea-pig olfactory cortex slices. J. Physiol. 1987, 382, 159-174. [CrossRef]

146. Kofuji, P.; Newman, E. Potassium buffering in the central nervous system. Neuroscience 2004, 129, 1043-1054. [CrossRef]

147. Rimmele, T.S.; Chatton, J.-Y. A Novel Optical Intracellular Imaging Approach for Potassium Dynamics in Astrocytes. PLoS ONE 2014, 9, e109243. [CrossRef]

148. Yan, Y.; Dempsey, R.J.; Sun, D. Expression of $\mathrm{Na}^{+}-\mathrm{K}^{+}-\mathrm{Cl}-$ cotransporter in rat brain during development and its localization in mature astrocytes. Brain Res. 2001, 911, 43-55. [CrossRef]

149. Olsen, M.L.; Sontheimer, H. Functional implications for Kir4.1 channels in glial biology: From $\mathrm{K}^{+}$buffering to cell differentiation. J. Neurochem. 2008, 107, 589-601. [CrossRef]

150. Milton, M.; Smith, P.D. It's All about Timing: The Involvement of Kir4.1 Channel Regulation in Acute Ischemic Stroke Pathology. Front. Cell. Neurosci. 2018, 12, 36. [CrossRef] [PubMed]

151. Leis, J.A.; Bekar, L.K.; Walz, W. Potassium homeostasis in the ischemic brain. Glia 2005, 50, 407-416. [CrossRef] [PubMed]

152. Menyhárt, Á.; Farkas, A.E.; Varga, D.P.; Frank, R.; Tóth, R.; Bálint, A.R.; Makra, P.; Dreier, J.P.; Bari, F.; Krizbai, I.A.; et al. Large-conductance $\mathrm{Ca}^{2+}$-activated potassium channels are potently involved in the inverse neurovascular response to spreading depolarization. Neurobiol. Dis. 2018, 119, 41-52. [CrossRef] [PubMed]

153. Varga, D.P.; Menyhárt, Á.; Puskás, T.; Bari, F.; Farkas, E.; Kis, Z.; Vécsei, L.; Toldi, J.; Gellért, L. Systemic administration of 1-kynurenine sulfate induces cerebral hypoperfusion transients in adult C57Bl/6 mice. Microvasc. Res. 2017, 114, 19-25. [CrossRef] 
154. Zhong, C.J.; Chen, M.M.; Lu, M.; Ding, J.H.; Du, R.H.; Hu, G. Astrocyte-specific deletion of Kir6.1/K-ATP channel aggravates cerebral ischemia/reperfusion injury through endoplasmic reticulum stress in mice. Exp. Neurol. 2019, 311, 225-233. [CrossRef]

155. Su, G.; Kintner, D.B.; Flagella, M.; Shull, G.E.; Sun, D. Astrocytes from $\mathrm{Na}^{+}-\mathrm{K}^{+}-\mathrm{Cl}-$ cotransporter-null mice exhibit absence of swelling and decrease in EAA release. Am. J. Physiol. Physiol. 2002, 282, C1147-C1160. [CrossRef] [PubMed]

156. Lenart, B.; Kintner, D.B.; Shull, G.E.; Sun, D. Na-K-Cl Cotransporter-Mediated Intracellular $\mathrm{Na}^{+} \mathrm{Accum}$ ulation Affects Ca ${ }^{2+}$ Signaling in Astrocytes in an In Vitro Ischemic Model. J. Neurosci. 2004, 24, 9585-9597. [CrossRef]

157. Luo, J.; Wang, Y.; Chen, H.; Kintner, D.B.; Cramer, S.W.; Gerdts, J.K.; Chen, X.; Shull, G.E.; Philipson, K.D.; Sun, D. A concerted role of $\mathrm{Na}^{+}-\mathrm{K}^{+}-\mathrm{Cl}-$ cotransporter and $\mathrm{Na}^{+} / \mathrm{Ca}^{2+}$ exchanger in ischemic damage. J. Cereb. Blood Flow Metab. 2008, 28, 737-746. [CrossRef]

158. Deitmer, J.W.; Theparambil, S.M.; Ruminot, I.; Noor, S.I.; Becker, H.M. Energy Dynamics in the Brain: Contributions of Astrocytes to Metabolism and pH Homeostasis. Front. Neurosci. 2019, 13, 1301. [CrossRef]

159. Chesler, M. Failure and function of intracellular $\mathrm{pH}$ regulation in acute hypoxic-ischemic injury of astrocytes. Glia 2005, 50, 398-406. [CrossRef]

160. Deitmer, J.W.; Rose, C.R. pH regulation and proton signalling by glial cells. Prog. Neurobiol. 1996, 48, 73-103. [CrossRef]

161. Theparambil, S.M.; Hosford, P.S.; Ruminot, I.; Kopach, O.; Reynolds, J.R.; Sandoval, P.Y.; Rusakov, D.A.; Barros, L.F.; Gourine, A.V. Astrocytes regulate brain extracellular $\mathrm{pH}$ via a neuronal activity-dependent bicarbonate shuttle. Nat. Commun. 2020, 11, 1-15. [CrossRef] [PubMed]

162. Kraig, R.P.; Chesler, M. Astrocytic Acidosis in Hyperglycemic and Complete Ischemia. Br. J. Pharmacol. 1990, 10, 104-114. [CrossRef] [PubMed]

163. Yao, H.; Azad, P.; Zhao, H.W.; Wang, J.; Poulsen, O.; Freitas, B.C.; Muotri, A.R.; Haddad, G.G. The Na ${ }^{+} / \mathrm{HCO}^{-}$co-transporter is protective during ischemia in astrocytes. Neuroscience 2016, 339, 329-337. [CrossRef] [PubMed]

164. Bondarenko, A.; Chesler, M. Rapid astrocyte death induced by transient hypoxia, acidosis, and extracellular ion shifts. Glia 2001, 34, 134-142. [CrossRef]

165. Menyhart, A.; Zolei-Szenasi, D.; Puskas, T.; Makra, P.; Orsolya, M.T.; Szepes, B.E.; Toth, R.; Ivankovits-Kiss, O.; Obrenovitch, T.P.; Bari, F.; et al. Spreading depolarization remarkably exacerbates ischemia-induced tissue aci-dosis in the young and aged rat brain. Sci. Rep. 2017, 7, 1154. [CrossRef]

166. Swanson, R.A.; Farrell, K.; Simon, R.P. Acidosis Causes Failure of Astrocyte Glutamate Uptake during Hypoxia. Br. J. Pharmacol. 1995, 15, 417-424. [CrossRef] [PubMed]

167. Tóth, O.M.; Menyhárt, Á.; Frank, R.; Hantosi, D.; Farkas, E.; Bari, F. Tissue Acidosis Associated with Ischemic Stroke to Guide Neuroprotective Drug Delivery. Biology 2020, 9, 460. [CrossRef] [PubMed]

168. Mellergård, P.E.; Siesjö, B.K. Astrocytes fail to regulate intracellular pH at moderately reduced extracellular pH. NeuroReport 1991, 2, 695-698. [CrossRef]

169. Mutch, W.A.C.; Hansen, A.J. Extracellular pH Changes during Spreading Depression and Cerebral Ischemia: Mechanisms of Brain pH Regulation. Br. J. Pharmacol. 1984, 4, 17-27. [CrossRef]

170. Kintner, U.B.; Su, G.; Lenart, B.; Ballard, A.J.; Meyer, J.W.; Ng, L.L.; Shull, G.E.; Sun, D. Increased tolerance to oxygen and glucose deprivation in astrocytes from $\mathrm{Na}^{+} / \mathrm{H}^{+}$exchanger isoform 1 null mice. Am. J. Physiol. Physiol. 2004, 287, C12-C21. [CrossRef]

171. Bondarenko, A.; Svichar, N.; Chesler, M. Role of $\mathrm{Na}^{+}-\mathrm{H}^{+}$and $\mathrm{Na}^{+}-\mathrm{Ca}^{2+}$ exchange in hypoxia-related acute astrocyte death. Glia 2004, 49, 143-152. [CrossRef]

172. Giffard, R.G.; Papadopoulos, M.C.; van Hooft, J.A.; Xu, L.; Giuffrida, R.; Monyer, H. The electrogenic sodium bicar-bonate cotransporter: Developmental expression in rat brain and possible role in acid vulnerability. J. Neurosci. 2000, 20, 1001-1008. [CrossRef] [PubMed]

173. Larsen, B.R.; MacAulay, N. Activity-dependent astrocyte swelling is mediated by pH-regulating mechanisms. Glia 2017, 65, 1668-1681. [CrossRef]

174. Beppu, K.; Sasaki, T.; Tanaka, K.; Yamanaka, A.; Fukazawa, Y.; Shigemoto, R.; Matsui, K. Optogenetic Countering of Glial Acidosis Suppresses Glial Glutamate Release and Ischemic Brain Damage. Neuron 2014, 81, 314-320. [CrossRef] [PubMed]

175. Sloan, S.A.; Barres, B.A. The detrimental role of glial acidification during ischemia. Neuron 2014, 81, 221-223. [CrossRef]

176. Wilson, C.S.; Mongin, A.A. Cell Volume Control in Healthy Brain and Neuropathologies. In Current Topics in Membranes; Academic Press: New York, NY, USA, 2018; Volume 81, pp. 385-455.

177. Hübel, N.; Ullah, G. Anions Govern Cell Volume: A Case Study of Relative Astrocytic and Neuronal Swelling in Spreading Depolarization. PLoS ONE 2016, 11, e0147060. [CrossRef]

178. MacAulay, N.; Zeuthen, T. Water transport between CNS compartments: Contributions of aquaporins and cotrans-porters. Neuroscience 2010, 168, 941-956. [CrossRef]

179. Papadopoulos, M.; Verkman, A.S. Aquaporin water channels in the nervous system. Nat. Rev. Neurosci. 2013, 14, 265-277. [CrossRef]

180. Andrew, R.D.; Labron, M.W.; Boehnke, S.E.; Carnduff, L.; Kirov, S.A. Physiological Evidence That Pyramidal Neurons Lack Functional Water Channels. Cereb. Cortex 2006, 17, 787-802. [CrossRef]

181. Nagelhus, E.A.; Ottersen, O.P. Physiological Roles of Aquaporin-4 in Brain. Physiol. Rev. 2013, 93, 1543-1562. [CrossRef] [PubMed]

182. Delpire, E.; Staley, K.J. Novel determinants of the neuronal Cl—concentration. J. Physiol. 2014, 592, 4099-4114. [CrossRef] 
183. Wilson, C.S.; Mongin, A.A. The signaling role for chloride in the bidirectional communication between neurons and astrocytes. Neurosci. Lett. 2019, 689, 33-44. [CrossRef]

184. Kettenmann, H.; Backus, K.H.; Schachner, M. gamma-Aminobutyric acid opens Cl-channels in cultured astrocytes. Brain Res. 1987, 404, 1-9. [CrossRef]

185. Bevensee, M.O.; Apkon, M.; Boron, W.F. Intracellular $\mathrm{pH}$ regulation in cultured astrocytes from rat hippocampus. II. Electrogenic $\mathrm{Na} / \mathrm{HCO} 3$ cotransport. J. Gen. Physiol. 1997, 110, 467-483. [CrossRef]

186. Kimelberg, H. Active accumulation and exchange transport of chloride in astroglial cells in culture. Biochim. et Biophys. Acta (BBA) Biomembr. 1981, 646, 179-184. [CrossRef]

187. Walz, W.; Mukerji, S. KCl movements during potassium-induced cytotoxic swelling of cultured astrocytes. Exp. Neurol. 1988, 99, 17-29. [CrossRef]

188. Bekar, L.K.; Walz, W. Intracellular chloride modulates A-type potassium currents in astrocytes. Glia 2002, 39, 207-216. [CrossRef]

189. Smith, Q.R.; Johanson, C.E.; Woodbury, D.M. Uptake of $36 \mathrm{Cl}$ and $22 \mathrm{Na}$ by the brain-cerebrospinal fluid system: Comparison of the permeability of the blood-brain and blood-cerebrospinal fluid barriers. J. Neurochem. 1981, 37, 117-124. [CrossRef] [PubMed]

190. Marandi, N.; Konnerth, A.; Garaschuk, O. Two-photon chloride imaging in neurons of brain slices. Pflügers Arch. Eur. J. Physiol. 2002, 445, 357-365. [CrossRef]

191. Kovalchuk, Y.; Garaschuk, O. Two-Photon Chloride Imaging Using MQAE In Vitro and In Vivo. Cold Spring Harb. Protoc. 2012, 2012, 778-785. [CrossRef] [PubMed]

192. Gensch, T.; Untiet, V.; Franzen, A.; Kovermann, P.; Fahlke, C. Determination of Intracellular Chloride Concentrations by Fluorescence Lifetime Imaging. In Springer Series in Chemical Physics; Metzler, J.B., Ed.; Springer: Cham, Switzerland, 2015; pp. 189-211.

193. Untiet, V.; Kovermann, P.; Gerkau, N.J.; Gensch, T.; Rose, C.R.; Fahlke, C. Glutamate transporter-associated anion channels adjust intracellular chloride concentrations during glial maturation. Glia 2017, 65, 388-400. [CrossRef] [PubMed]

194. MacVicar, B.A.; Tse, F.W.; Crichton, S.A.; Kettenmann, H. GABA-activated Cl- channels in astrocytes of hippocampal slices. J. Neurosci. 1989, 9, 3577-3583. [CrossRef] [PubMed]

195. Muller, T.; Fritschy, J.M.; Grosche, J.; Pratt, G.D.; Mohler, H.; Kettenmann, H. Developmental regulation of voltage-gated K channel and GABAA receptor expression in Bergmann glial cells. J. Neurosci. 1994, 14, 2503-2514. [CrossRef]

196. Egawa, K.; Yamada, J.; Furukawa, T.; Yanagawa, Y.; Fukuda, A. Cl—homeodynamics in gap junction-coupled astrocytic networks on activation of GABAergic synapses. J. Physiol. 2013, 591, 3901-3917. [CrossRef] [PubMed]

197. Meier, S.D.; Kafitz, K.W.; Rose, C.R. Developmental profile and mechanisms of GABA-induced calcium signaling in hippocampal astrocytes. Glia 2008, 56, 1127-1137. [CrossRef]

198. Kahle, K.T.; Khanna, A.R.; Alper, S.L.; Adragna, N.C.; Lauf, P.K.; Sun, D.; Delpire, E. K-Cl cotransporters, cell volume homeostasis, and neurological disease. Trends Mol. Med. 2015, 21, 513-523. [CrossRef] [PubMed]

199. Gagnon, K.B.; Delpire, E. Physiology of SLC12 transporters: Lessons from inherited human genetic mutations and genetically engineered mouse knockouts. Am. J. Physiol. Physiol. 2013, 304, C693-C714. [CrossRef]

200. Mount, D.B.; Mercado, A.; Song, L.; Xu, J.; George, A.L., Jr.; Delpire, E.; Gamba, G. Cloning and Characterization of KCC3 and KCC4, New Members of the Cation-Chloride Cotransporter Gene Family. J. Biol. Chem. 1999, 274, 16355-16362. [CrossRef]

201. Su, G.; Kintner, U.B.; Sun, D. Contribution of $\mathrm{Na}^{+}-\mathrm{K}^{+}-\mathrm{Cl}-$ cotransporter to high- $\left[\mathrm{K}^{+}\right] \mathrm{o}-$ induced swelling and EAA release in astrocytes. Am. J. Physiol. Physiol. 2002, 282, C1136-C1146. [CrossRef]

202. Fairman, W.A.; Vandenberg, R.J.; Arriza, J.L.; Kavanaught, M.P.; Amara, S. An excitatory amino-acid transporter with properties of a ligand-gated chloride channel. Nat. Cell Biol. 1995, 375, 599-603. [CrossRef] [PubMed]

203. Wadiche, J.; Amara, S.; Kavanaugh, M.P. Ion fluxes associated with excitatory amino acid transport. Neuron 1995, 15, 721-728. [CrossRef]

204. Larsson, H.; Picaud, S.; Werblin, F.; Lecar, H. Noise analysis of the glutamate-activated current in photoreceptors. Biophys. J. 1996, 70, 733-742. [CrossRef]

205. Machtens, J.-P.; Kortzak, D.; Lansche, C.; Leinenweber, A.; Kilian, P.; Begemann, B.; Zachariae, U.; Ewers, D.; De Groot, B.L.; Briones, R.; et al. Mechanisms of Anion Conduction by Coupled Glutamate Transporters. Cell 2015, 160, 542-553. [CrossRef]

206. Cheng, M.H.; Torres-Salazar, D.; Gonzalez-Suarez, A.D.; Amara, S.G.; Bahar, I. Substrate transport and anion permeation proceed through distinct pathways in glutamate transporters. eLife 2017, 6, 6. [CrossRef]

207. Fahlke, C.; Kortzak, D.; Machtens, J.-P. Molecular physiology of EAAT anion channels. Pflügers Arch. Eur. J. Physiol. 2016, 468, 491-502. [CrossRef]

208. Regan, M.R.; Huang, Y.H.; Kim, Y.S.; Dykes-Hoberg, M.I.; Jin, L.; Watkins, A.M.; Bergles, D.E.; Rothstein, J.D. Variations in promoter activity reveal a differential expression and physiology of glutamate transporters by glia in the devel-oping and mature CNS. J. Neurosci. 2007, 27, 6607-6619. [CrossRef]

209. Jen, J.C.; Wan, J.; Palos, T.P.; Howard, B.D.; Baloh, R.W. Mutation in the glutamate transporter EAAT1 causes episodic ataxia, hemiplegia, and seizures. Neurology 2005, 65, 529-534. [CrossRef]

210. Kovermann, P.; Untiet, V.; Kolobkova, Y.; Engels, M.; Baader, S.; Schilling, K.; Fahlke, C. Increased glutamate trans-porterassociated anion currents cause glial apoptosis in episodic ataxia 6. Brain Commun. 2020, 2, fcaa022. [CrossRef] [PubMed]

211. Winter, N.; Kovermann, P.; Fahlke, C. A point mutation associated with episodic ataxia 6 increases glutamate trans-porter anion currents. Brain 2012, 135, 3416-3425. [CrossRef] 
212. Pfeffer, C.K.; Stein, V.; Keating, D.J.; Maier, H.; Rinke, I.; Rudhard, Y.; Hentschke, M.; Rune, G.M.; Jentsch, T.J.; Hubner, C.A. NKCC1-dependent GABAergic excitation drives synaptic network maturation during early hippocampal de-velopment. J. Neurosci. 2009, 29, 3419-3430. [CrossRef] [PubMed]

213. Delpire, E.; Lu, J.; England, R.; Dull, C.; Thorne, T. Deafness and imbalance associated with inactivation of the secretory Na-K-2Cl co-transporter. Nat. Genet. 1999, 22, 192-195. [CrossRef] [PubMed]

214. MacNamara, E.F.; Koehler, A.E.; D'Souza, P.; Estwick, T.; Lee, P.; Vezina, G.; Fauni, H.; Braddock, S.R.; Torti, E.; Holt, J.M.; et al. Kilquist syndrome: A novel syndromic hearing loss disorder caused by homozygous deletion of SLC12A2. Hum. Mutat. 2019, 40, 532-538. [CrossRef]

215. Delpire, E.; Wolfe, L.; Flores, B.; Koumangoye, R.; Schornak, C.C.; Omer, S.; Pusey, B.; Lau, C.; Markello, T.; Adams, D.R. A patient with multisystem dysfunction carries a truncation mutation in humanSLC12A2, the gene encoding the Na-K-2Cl cotransporter, NKCC1. Mol. Case Stud. 2016, 2, a001289. [CrossRef] [PubMed]

216. Yan, Q.; Matheson, C.; Sun, J.; Radeke, M.; Feinstein, S.; Miller, J. Distribution of Intracerebral Ventricularly Administered Neurotrophins in Rat Brain and Its Correlation with Trk Receptor Expression. Exp. Neurol. 1994, 127, 23-36. [CrossRef] [PubMed]

217. Yan, Y.; Dempsey, R.J.; Sun, D. $\mathrm{Na}^{+}-\mathrm{K}^{+}-\mathrm{Cl}-$ Cotransporter in Rat Focal Cerebral Ischemia. Br. J. Pharmacol. 2001, 21, 711-721. [CrossRef]

218. Chen, H.; Sun, D. The role of Na-K-Cl co-transporter in cerebral ischemia. Neurol. Res. 2005, 27, 280-286. [CrossRef]

219. Chen, H.; Luo, J.; Kintner, D.B.; Shull, G.E.; Sun, D. Na ${ }^{+}$-Dependent Chloride Transporter (NKCC1)-Null Mice Exhibit Less Gray and White Matter Damage after Focal Cerebral Ischemia. Br. J. Pharmacol. 2005, 25, 54-66. [CrossRef] [PubMed]

220. Huang, H.; Bhuiyan, M.I.H.; Jiang, T.; Song, S.; Shankar, S.; Taheri, T.; Li, E.; Schreppel, P.; Hintersteininger, M.; Yang, S.-S.; et al. A Novel Na+-K+-Cl- Cotransporter 1 Inhibitor STS66* Reduces Brain Damage in Mice After Ischemic Stroke. Stroke 2019, 50, 1021-1025. [CrossRef]

221. Inoue, H.; Okada, Y. Roles of Volume-Sensitive Chloride Channel in Excitotoxic Neuronal Injury. J. Neurosci. 2007, 27, 1445-1455. [CrossRef] [PubMed]

222. Pedersen, S.F.; Okada, Y.; Nilius, B. Biophysics and Physiology of the Volume-Regulated Anion Channel (VRAC)/VolumeSensitive Outwardly Rectifying Anion Channel (VSOR). Pflügers Arch. Eur. J. Physiol. 2016, 468, 371-383. [CrossRef]

223. Strange, K.; Yamada, T.; Denton, J.S. A 30-year journey from volume-regulated anion currents to molecular structure of the LRRC8 channel. J. Gen. Physiol. 2019, 151, 100-117. [CrossRef]

224. Wilson, C.S.; Bach, M.D.; Ashkavand, Z.; Norman, K.R.; Martino, N.; Adam, A.P.; Mongin, A.A. Metabolic constraints of swelling-activated glutamate release in astrocytes and their implication for ischemic tissue damage. J. Neurochem. 2019, 151, 255-272. [CrossRef] [PubMed]

225. Sacher, A.; Nelson, N.; Ogi, J.T.; Wright, E.M.; Loo, D.D.; Eskandari, S. Presteady-state and steady-state kinetics and turnover rate of the mouse gamma-aminobutyric acid transporter (mGAT3). J. Membr. Biol. 2002, 190, 57-73. [CrossRef]

226. Loo, D.D.; Eskandari, S.; Boorer, K.J.; Sarkar, H.K.; Wright, E.M. Role of Cl- in Electrogenic $\mathrm{Na}^{+}$-coupled Cotransporters GAT1 and SGLT1. J. Biol. Chem. 2000, 275, 37414-37422. [CrossRef]

227. Roux, M.J.; Supplisson, S. Neuronal and Glial Glycine Transporters Have Different Stoichiometries. Neuron 2000, 25, 373-383. [CrossRef]

228. Zomot, E.; Bendahan, A.; Quick, M.; Zhao, Y.; Javitch, J.A.; Kanner, B.I. Mechanism of chloride interaction with neurotransmitter:sodium symporters. Nature 2007, 449, 726-730. [CrossRef] [PubMed]

229. Hodgkin, A.L.; Horowicz, P. The influence of potassium and chloride ions on the membrane potential of single muscle fibres. J. Physiol. 1959, 148, 127-160. [CrossRef] [PubMed]

230. Dulhunty, A.F. The dependence of membrane potential on extracellular chloride concentration in mammalian skeletal muscle fibres. J. Physiol. 1978, 276, 67-82. [CrossRef] [PubMed]

231. Habela, C.W.; Ernest, N.J.; Swindall, A.F.; Sontheimer, H. Chloride Accumulation Drives Volume Dynamics Underlying Cell Proliferation and Migration. J. Neurophysiol. 2009, 101, 750-757. [CrossRef]

232. Sachs, F.; Sivaselvan, M.V. Cell volume control in three dimensions: Water movement without solute movement. J. Gen. Physiol. 2015, 145, 373-380. [CrossRef] [PubMed]

233. Mongin, A.A.; Orlov, S.N. Mechanisms of cell volume regulation and possible nature of the cell volume sensor. Pathophysiol. 2001, 8, 77-88. [CrossRef]

234. Benfenati, V.; Ferroni, S. Water transport between CNS compartments: Functional and molecular interactions between aquaporins and ion channels. Neuroscience 2010, 168, 926-940. [CrossRef] [PubMed]

235. Rungta, R.L.; Choi, H.B.; Tyson, J.R.; Malik, A.; Dissing-Olesen, L.; Lin, P.J.; Cain, S.M.; Cullis, P.R.; Snutch, T.P.; MacVicar, B.A. The Cellular Mechanisms of Neuronal Swelling Underlying Cytotoxic Edema. Cell 2015, 161, 610-621. [CrossRef] [PubMed]

236. Nelson, N. The vacuolar H(+)-ATPase-one of the most fundamental ion pumps in nature. J. Exp. Biol. 1992, 172, 19-27. [CrossRef]

237. Lloyd, A.C. The Regulation of Cell Size. Cell 2013, 154, 1194-1205. [CrossRef]

238. Gurtovenko, A.A.; Vattulainen, I. Ion Leakage through Transient Water Pores in Protein-Free Lipid Membranes Driven by Transmembrane Ionic Charge Imbalance. Biophys. J. 2007, 92, 1878-1890. [CrossRef] [PubMed]

239. Fischbarg, J.; Kuang, K.Y.; Vera, J.C.; Arant, S.; Silverstein, S.C.; Loike, J.; Rosen, O.M. Glucose transporters serve as water channels. Proc. Natl. Acad. Sci. USA 1990, 87, 3244-3247. [CrossRef] [PubMed] 
240. Toft-Bertelsen, T.L.; Larsen, B.R.; Christensen, S.K.; Khandelia, H.; Waagepetersen, H.S.; MacAulay, N. Clearance of activityevoked $\mathrm{K}(+)$ transients and associated glia cell swelling occur independently of AQP4: A study with an iso-form-selective AQP4 inhibitor. Glia 2021, 69, 28-41. [CrossRef]

241. Iwamoto, M.; Oiki, S. Counting Ion and Water Molecules in a Streaming File through the Open-Filter Structure of the K Channel. J. Neurosci. 2011, 31, 12180-12188. [CrossRef] [PubMed]

242. Ulmschneider, M.B.; Bagnéris, C.; McCusker, E.C.; DeCaen, P.G.; Delling, M.; Clapham, D.E.; Ulmschneider, J.P.; Wallace, B.A. Molecular dynamics of ion transport through the open conformation of a bacterial voltage-gated sodium channel. Proc. Natl. Acad. Sci. USA 2013, 110, 6364-6369. [CrossRef]

243. Ando, H.; Kuno, M.; Shimizu, H.; Muramatsu, I.; Oiki, S. Coupled K+-Water Flux through the HERG Potassium Channel Measured by an Osmotic Pulse Method. J. Gen. Physiol. 2005, 126, 529-538. [CrossRef]

244. Vella, J.; Zammit, C.; Di Giovanni, G.; Muscat, R.; Valentino, M. The central role of aquaporins in the pathophysiology of ischemic stroke. Front. Cell. Neurosci. 2015, 9, 108. [CrossRef] [PubMed]

245. Andrew, R.D.; Hsieh, Y.-T.; Brisson, C.D. Spreading depolarization triggered by elevated potassium is weak or absent in the rodent lower brain. Br. J. Pharmacol. 2016, 37, 1735-1747. [CrossRef]

246. Hoffmann, E.K.; Lambert, I.H.; Pedersen, S.F. Physiology of Cell Volume Regulation in Vertebrates. Physiol. Rev. 2009, 89, 193-277. [CrossRef]

247. Zeuthen, T. Water-Transporting Proteins. J. Membr. Biol. 2009, 234, 57-73. [CrossRef] [PubMed]

248. Stokum, J.A.; Gerzanich, V.; Simard, J.M. Molecular pathophysiology of cerebral edema. Br. J. Pharmacol. 2016, 36, 513-538. [CrossRef]

249. Yao, Y.; Zhang, Y.; Liao, X.; Yang, R.; Lei, Y.; Luo, J. Potential Therapies for Cerebral Edema After Ischemic Stroke: A Mini Review. Front. Aging Neurosci. 2021, 12, 618819. [CrossRef]

250. Hofmeijer, J.; Kappelle, L.J.; Algra, A.; Amelink, G.J.; van Gijn, J.; van der Worp, H.B.; Investigators, H. Surgical de-compression for space-occupying cerebral infarction (the Hemicraniectomy After Middle Cerebral Artery infarction with Life-threatening Edema Trial [HAMLET]): A multicentre, open, randomised trial. Lancet Neurol. 2009, 8, 326-333. [CrossRef]

251. Nelson, P. Biological Physics. Energy, Information, Life; W.H. Freeman and Company: New York, NY, USA, 2008.

252. Van Putten, M.J.A.M. Dynamics of Neural Networks: A Mathematical and Clinical Approach; Springer: Berlin/Heidelberg, Germany, 2020.

253. Plonsey, R.; Barr, R.C. Bioelecticity: A Qunantitarive Approach; Spinger: Berlin/Heidelberg, Germany, 2007.

254. Dijkstra, K.; Hofmeijer, J.; van Gils, S.A.; van Putten, M.J.A.M. A Biophysical Model for Cytotoxic Cell Swelling. J. Neurosci. 2016, 36, 11881-11890. [CrossRef] [PubMed]

255. Jin, B.-J.; Zhang, H.; Binder, D.K.; Verkman, A. Aquaporin-4-dependent $\mathrm{K}^{+}$and water transport modeled in brain extracellular space following neuroexcitation. J. Gen. Physiol. 2013, 141, 119-132. [CrossRef]

256. Halnes, G.; Østby, I.; Pettersen, K.H.; Omholt, S.W.; Einevoll, G.T. Electrodiffusive Model for Astrocytic and Neuronal Ion Concentration Dynamics. PLoS Comput. Biol. 2013, 9, e1003386. [CrossRef] [PubMed]

257. Hübel, N.; Andrew, R.D.; Ullah, G. Large extracellular space leads to neuronal susceptibility to ischemic injury in a $\mathrm{Na}^{+} / \mathrm{K}^{+}$ pumps-dependent manner. J. Comput. Neurosci. 2016, 40, 177-192. [CrossRef] [PubMed]

258. Kalia, M.; Meijer, H.G.E.; van Gils, S.A.; van Putten, M.J.A.M.; Rose, C.R. Ion dynamics at the energy-deprived tripartite synapse. bioRxiv 2021, arXiv:2021.03.19.436129.

259. Glykys, J.; Dzhala, V.; Egawa, K.; Kahle, K.T.; Delpire, E.; Staley, A. Chloride dysregulation, seizures, and cerebral edema: A relationship with therapeutic potential Trends. Neurosciences 2017, 40, 276-294. [CrossRef] [PubMed]

260. Liang, J.; Suryanarayanan, A.; Chandra, D.; Homanics, G.E.; Olsen, R.W.; Spigelman, I. Functional Consequences of GABAA Receptor $\alpha 4$ Subunit Deletion on Synaptic and Extrasynaptic Currents in Mouse Dentate Granule Cells. Alcohol. Clin. Exp. Res. 2007, 32, 19-26. [CrossRef] [PubMed]

261. Tong, J.; Briggs, M.M.; McIntosh, T.J. Water Permeability of Aquaporin-4 Channel Depends on Bilayer Composition, Thickness, and Elasticity. Biophys. J. 2012, 103, 1899-1908. [CrossRef]

262. Pangršič, T.; Potokar, M.; Haydon, P.G.; Zorec, R.; Kreft, M. Astrocyte swelling leads to membrane unfolding, not membrane insertion. J. Neurochem. 2006, 99, 514-523. [CrossRef] [PubMed]

263. Ito, U.; Ohno, K.; Nakamura, R.; Suganuma, F.; Inaba, Y. Brain edema during ischemia and after restoration of blood flow. Measurement of water, sodium, potassium content and plasma protein permeability. Stroke 1979, 10, 542-547. [CrossRef]

264. Michinaga, S.; Koyama, Y. Pathogenesis of Brain Edema and Investigation into Anti-Edema Drugs. Int. J. Mol. Sci. 2015, 16, 9949-9975. [CrossRef]

265. Hladky, S.B.; Barrand, M.A. Mechanisms of fluid movement into, through and out of the brain: Evaluation of the evidence. Fluids Barriers CNS 2014, 11, 1-32. [CrossRef] [PubMed]

266. Nzou, G.; Wicks, R.T.; VanOstrand, N.R.; Mekky, G.A.; Seale, S.A.; El-Taibany, A.; Wicks, E.E.; Nechtman, C.M.; Marrotte, E.J.; Makani, V.S.; et al. Multicellular 3D Neurovascular Unit Model for Assessing Hypoxia and Neuroinflammation Induced Blood-Brain Barrier Dysfunction. Sci. Rep. 2020, 10, 9766. [CrossRef]

267. Dostovic, Z.; Dostovic, E.; Smajlovic, D.; Avdic, L.; Ibrahimagic, O.C. Brain Edema After Ischaemic Stroke. Med. Arch. 2016, 70, 339-341. [CrossRef] 
268. Abbruscato, T.J.; Lopez, S.P.; Roder, K.; Paulson, J.R. Regulation of Blood-Brain Barrier Na, K, 2Cl-Cotransporter through Phosphorylation during in Vitro Stroke Conditions and Nicotine Exposure. J. Pharmacol. Exp. Ther. 2004, 310, 459-468. [CrossRef] [PubMed]

269. Vemula, S.; Roder, K.E.; Yang, T.; Bhat, G.J.; Thekkumkara, T.J.; Abbruscato, T.J. A Functional Role for Sodium-Dependent Glucose Transport across the Blood-Brain Barrier during Oxygen Glucose Deprivation. J. Pharmacol. Exp. Ther. 2008, 328, 487-495. [CrossRef] [PubMed]

270. Abdullahi, W.; Tripathi, D.; Ronaldson, P.T. Blood-brain barrier dysfunction in ischemic stroke: Targeting tight junc-tions and transporters for vascular protection. Am. J. Physiol. Cell Physiol. 2018, 315, C343-C356. [CrossRef] [PubMed]

271. O'Donnell, M.E. Blood-Brain Barrier Na Transporters in Ischemic Stroke. Adv. Pharmacol. 2014, 71, 113-146. [CrossRef] [PubMed] 